\title{
Geology of Corundum and EMerald GeM DePosits: A ReVIEW
}

Gaston Giuliani and Lee A. Groat

The great challenge of geographic origin determination is to connect the properties and features of individual gems to the geology of their deposits. Similar geologic environments can produce gems with similar gemological properties, making it difficult to find unique identifiers. Over the last two decades, our knowledge of corundum and emerald deposit formation has improved significantly.

The mineral deposits are classically separated into primary and secondary deposits. Primary corundum deposits are subdivided into two types based on their geological environment of formation: (1) magmatic and (2) metamorphic. Magmatic deposits include gem corundum in alkali basalts as in eastern Australia, and sapphire in lamprophyre and syenite as in Montana (United States) and Garba Tula (Kenya), respectively. Metamorphic deposits are divided into two subtypes (1) metamorphic deposits sensu stricto (in marble; mafic and ultramafic rocks, or M-UMR), and (2) metamorphicmetasomatic deposits characterized by high fluid-rock interaction and metasomatism (i.e., plumasite or desilicated pegmatites in M-UMR and marble, skarn deposits, and shear zone-related deposits in different substrata, mainly corundum-bearing Mg-Cr-biotite schist). Examples of the first subtype include the ruby deposits in marble from the Mogok Stone Tract or those in M-UMR from Montepuez (Mozambique) and Aappaluttoq (Greenland). The second subtype concerns the sapphire from Kashmir hosted by plumasites in M-UMR.

Secondary corundum deposits (i.e., present-day placers) result from the erosion of primary corundum deposits. Here, corundum is found in the following types of deposits: eluvial (derived by in situ weathering or weathering plus gravitational movement), diluvial (scree or talus), colluvial (deposited at the base of slopes by rainwash, sheetwash, slow continuous downslope creep, or a combination of these

See end of article for About the Authors and Acknowledgments.

Gems \& Gemology, Vol. 55, No. 4, pp. 464-489,

http://dx.doi.org/10.5741/GEMS.55.4.464

(C) 2019 Gemological Institute of America processes), and alluvial (deposited by rivers). Today, most sapphires are produced from gem placers related to alkali basalts, as in eastern Australia or southern Vietnam, while placers in metamorphic environments, such as in Sri Lanka (Ratnapura, Elahera) and Madagascar (Ilakaka), produce the highest-quality sapphires. The colluvial Montepuez deposit in Mozambique provides a huge and stable supply of clean and very highquality rubies.

Primary emerald deposits are subdivided into two types based on their geological environment of formation: (1) tectonic-magmatic-related (Type I) and (2) tectonic-metamorphic-related (Type II). Several subtypes are defined and especially Type IA, hosted in MUMR, which accounts for about $70 \%$ of worldwide production (Brazil, Zambia, Russia, and others). It is characterized by the intrusion of pegmatites or quartz veins in M-UMR accompanied by huge hydrothermal fluid circulation and metasomatism with the formation of emerald-bearing desilicated pegmatite (plumasite) and biotite schist. Type IB in sedimentary rocks (China, Canada, Norway, Kazakhstan, and Australia) and Type IC in granitic rocks (Nigeria) are of minor importance.

The subtype Type IIA of metamorphic deposits is related to hydrothermal fluid circulation at high temperature, in thrust fault and/or shear zones within M-UMR of volcano-sedimentary series, such as at the Santa Terezinha de Goiás deposit in Brazil. The subtype Type IIB is showcased by the Colombian emerald deposits located in the Lower Cretaceous black shales of the Eastern Cordillera Basin. These are related to the circulation of hydrothermal basinal fluids in black shales, at $300-330^{\circ} \mathrm{C}$, that dissolved evaporites in (1) thrust and tear faults for the deposits of the western emerald zone (Yacopi, Coscuez, Muzo, Peñas Blancas, Cunas, and La Pita mines) and (2) a regional evaporite level intercalated in the black shales or the deposits of the eastern emerald zone (Gachalá, Chivor, and Macanal mining districts).

Secondary emerald deposits are unknown because emerald is too fragile to survive erosion and transport in rivers. 


\section{PART I: RUBY AND SAPPHIRE}

Ruby and sapphire are gem varieties of the mineral corundum. The chromophores are chromium $\left(\mathrm{Cr}^{3+}\right)$ in ruby, and iron and titanium $\left(\mathrm{Fe}^{2+}\right.$ and $\left.\mathrm{Ti}^{4+}\right)$ in blue sapphire. All other colors are termed fancy sapphires and are named on the basis of color (e.g., yellow sapphire). Another valuable colored sapphire is the orange-pink or pinkish orange variety called padparadscha, derived from names for the lotus blossom. In this paper, the pink corundum associated with ruby worldwide (such as in the marble-type deposits) and called "pink sapphire" in the literature is considered to be genetically associated with ruby and not sapphire of other colors.

\section{In Brief}

- The classification systems of corundum and emerald deposits are based on different mineralogical and geological features.

- Corundum deposits are subdivided into primary (magmatic and metamorphic) and secondary (i.e., presentday placer) deposits.

- Emerald deposits are only primary and are subdivided into two types: (1) tectonic-magmatic-related and (2) tectonic-metamorphic-related.

- Today most gem sapphires are produced by placers in metamorphic and alkali basalt environments. Most rubies are produced by placers in metamorphic environments (marble and amphibolite rocks).

Geographic Distribution and Economic Significance. Corundum is found on all five continents. The highest-quality ruby crystals come from Central and Southeast Asia and Mozambique (SRK Consulting, 2015). Myanmar, with the Mogok Stone Tract, has produced "pigeon's blood" rubies since $600 \mathrm{CE}$ (Hughes, 1997). The world's finest blue sapphire comes from Kashmir (Sumjam), Myanmar, Sri Lanka (figure 1), and Madagascar. Sri Lanka is so far the most important producer of excellent padparadscha sapphire (Hughes, 1997).

The value of natural ruby and sapphire is based on the classic Four C's (color, clarity, cut, and carat weight) but also on the geographic origin. Enhancements and treatments are also of importance in the final evaluation, and it is very rare to find gem corundum that has not been heat-treated (Themelis, 1992).

Ruby and sapphire are the most important colored gemstones in the gem trade, and together they ac-

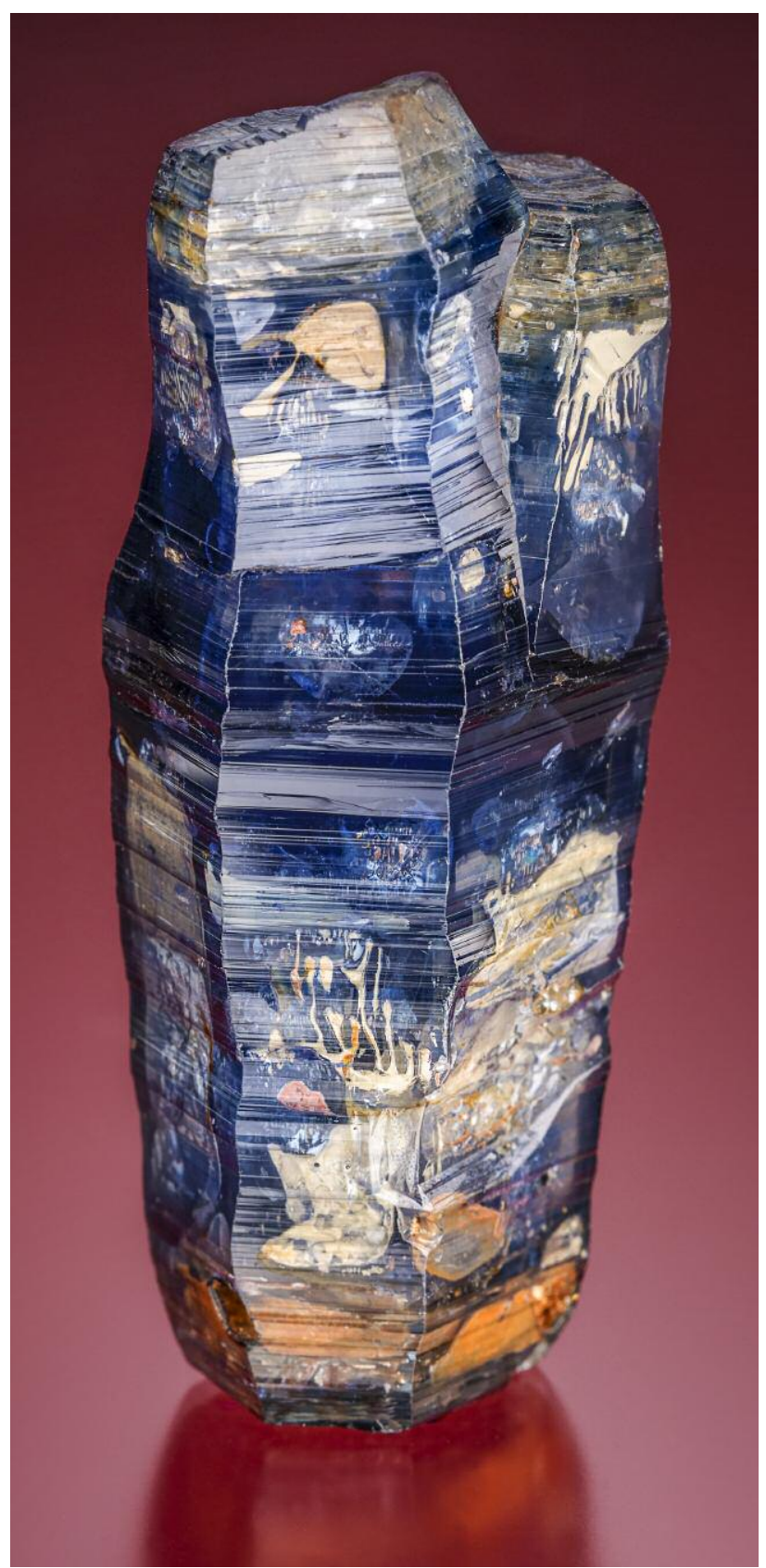

Figure 1. A 245.12 ct sapphire crystal from Kataragama, Sri Lanka, measuring $5.70 \times 2.15 \times 1.85 \mathrm{~cm}$. Photo by Robert Weldon/GIA; courtesy of Brent Lockhart.

count for more than $50 \%$ of global colored gem production (Hughes, 1997). Top-quality ruby is perhaps the world's most expensive gemstone, and the finest Mogok rubies are more highly valued than equivalent-sized flawless colorless diamonds. The world record price for a single ruby sold at auction belongs to the Sunrise Ruby, sold by Sotheby's in 2015 for $\$ 32.42$ million (\$1.27 million per carat at $25.59 \mathrm{ct}$ ). 
In December 2015, the 15.04 ct Crimson Flame ruby sold for $\$ 18.3$ million (\$1.21 million per carat). Another notable ruby is the 10.05 ct Ratnaraj, which sold for $\$ 10.2$ million (just over $\$ 1$ million per carat) in November 2017 ("Ratnaraj ruby ring highlight...," 2017). The world record price paid for a single blue sapphire is $\$ 17.30$ million for the 392.52 ct Blue Bell of Asia (\$44,063 per carat) at a 2014 Christie's auction. However, the world record price per carat belongs to an unnamed $27.68 \mathrm{ct} \mathrm{Kashmir} \mathrm{blue} \mathrm{sapphire}$ that sold at a 2015 Christie's auction for $\$ 6.75$ million, or $\$ 243,703$ per carat. Unheated ruby from the Didy mine in Madagascar also commands high prices (Pardieu and Rakotosaona, 2012). Peretti and Hahn (2013) reported that a set of eight faceted rubies, ranging from 7 to more than 14 ct apiece, had an estimated market value of $\$ 10$ million.

The discovery of the Montepuez ruby deposits in Mozambique in May 2009 (Pardieu et al., 2009), and their extraction by various companies, including Gemfields (Pardieu, 2018; Simonet, 2018), changed the international ruby market. SRK Consulting (2015) forecasted production of 432 million carats over 21 years. The resource at Montepuez is divided into primary reserves of 253 million carats (a projection of 115 carats per ton) and secondary (mainly colluvial) reserves of 179 million carats (a projection of 7.07 carats per ton). Nine Montepuez auctions held since June 2014 have generated \$335 million in aggregate revenue (Pardieu, 2018).

Age of the Deposits. The global distribution of corundum deposits is closely linked to plate tectonics-collision, rift, and subduction geodynamics (Giuliani et al., 2007a). Direct dating of corundum is impossible due to the absence of a suitable geochronometer. Ages are defined by indirect dating of a series of minerals (zircon, monazite, rutile, and micas), either in the host rocks or as syngenetic inclusions in the corundum (please refer to the Glossary for boldfaced terms). These minerals have different blocking temperatures closed to isotopic migration that make it possible to establish a cooling history for corundum.

Four main periods of corundum formation are recognized worldwide (Giuliani et al., 2007a; Graham et al., 2008). The oldest deposit is located in the Archean metamorphic series (2.97-2.6 billion years ago, or Ga) of southwest Greenland. The Aappaluttoq ruby deposit in the $2.97 \mathrm{Ga}$ Fiskenæsset anorthosite complex contains a sequence of thick olivine-ultra- mafic rocks intruded by leucogabbros that underwent a high degree of metamorphism at $2.82 \mathrm{Ma}$ (U$\mathrm{Pb}$ dating of monazite; Fagan, 2018). The contact between the ultramafic rock and the leucogabbro was the focus of intense fluid-rock interaction at 2.66 $\mathrm{Ga}$ (U-Pb dating of monazite) with ruby formation in phlogopite rocks (Krebs et al., 2019).

The second period of corundum formation was the Pan-African orogeny (750-450 Ma). This includes primary ruby and sapphire deposits in the gemstone belt of East Africa, Madagascar, India, and Sri Lanka that are linked to collisional processes between eastern and western Gondwana (figure 2) during PanAfrican tectonic-metamorphic events (Kröner, 1984). The metamorphic corundum deposits in southern Madagascar have numerous geological similarities with those in East Africa, Sri Lanka, and southern India (see Giuliani et al., 2014). U-Pb dating of zircon in host rocks of ruby from the John Saul mine in the Mangare area of Kenya (612 $\pm 6 \mathrm{Ma}$; Simonet, 2000), Longido in Tanzania $(610 \pm 6 \mathrm{Ma}$; Le Goff et al., 2010), and the Vohibory deposits in Madagascar (612 $\pm 5 \mathrm{Ma}$; Jöns and Schenk, 2008) revealed similar periods of formation related to the East African orogeny. U-Pb dating of rutile inclusions in ruby from the different ruby mines at Mangare has indicated cooling ages between $533 \pm 11$ and $526 \pm 13 \mathrm{Ma}$ (Sorokina et al., 2017a). Moreover, the U-Pb ages of zircon coeval with blue sapphire in the Andranondambo skarn deposit in southern Madagascar range from 523 to $510 \mathrm{Ma}$ (Paquette et al., 1994). These different ages confirm the existence of a metamorphic corundum episode, between 600 and $500 \mathrm{Ma}$, during the late Pan-African orogenic cycle (Cambrian period), and corresponding to the Kuunga orogeny.

The third period corresponds to the Cenozoic Himalayan orogeny (45 Ma to the Quaternary). Examples include the marble-hosted ruby deposits in Central and Southeast Asia, which occur in metamorphic blocks that were affected by major tectonic events during the collision of the Indian and Eurasian plates (Garnier et al., 2008). The ruby has been indirectly dated by ${ }^{40} \mathrm{Ar} /{ }^{39} \mathrm{Ar}$ stepwise heating experiments performed on single grains of coeval phlogopite, and by ion-probe U-Pb analyses of zircon included in the corundum (Graham et al., 2008; Giuliani et al., 2014). All of the Oligocene to Pliocene ages (40-5 Ma) are consistent with compressional tectonic events that were active in the ruby-bearing metamorphic belt from Afghanistan to Vietnam.

The fourth period of corundum formation is dominated by the extrusion of alkali basalts in the Ceno- 

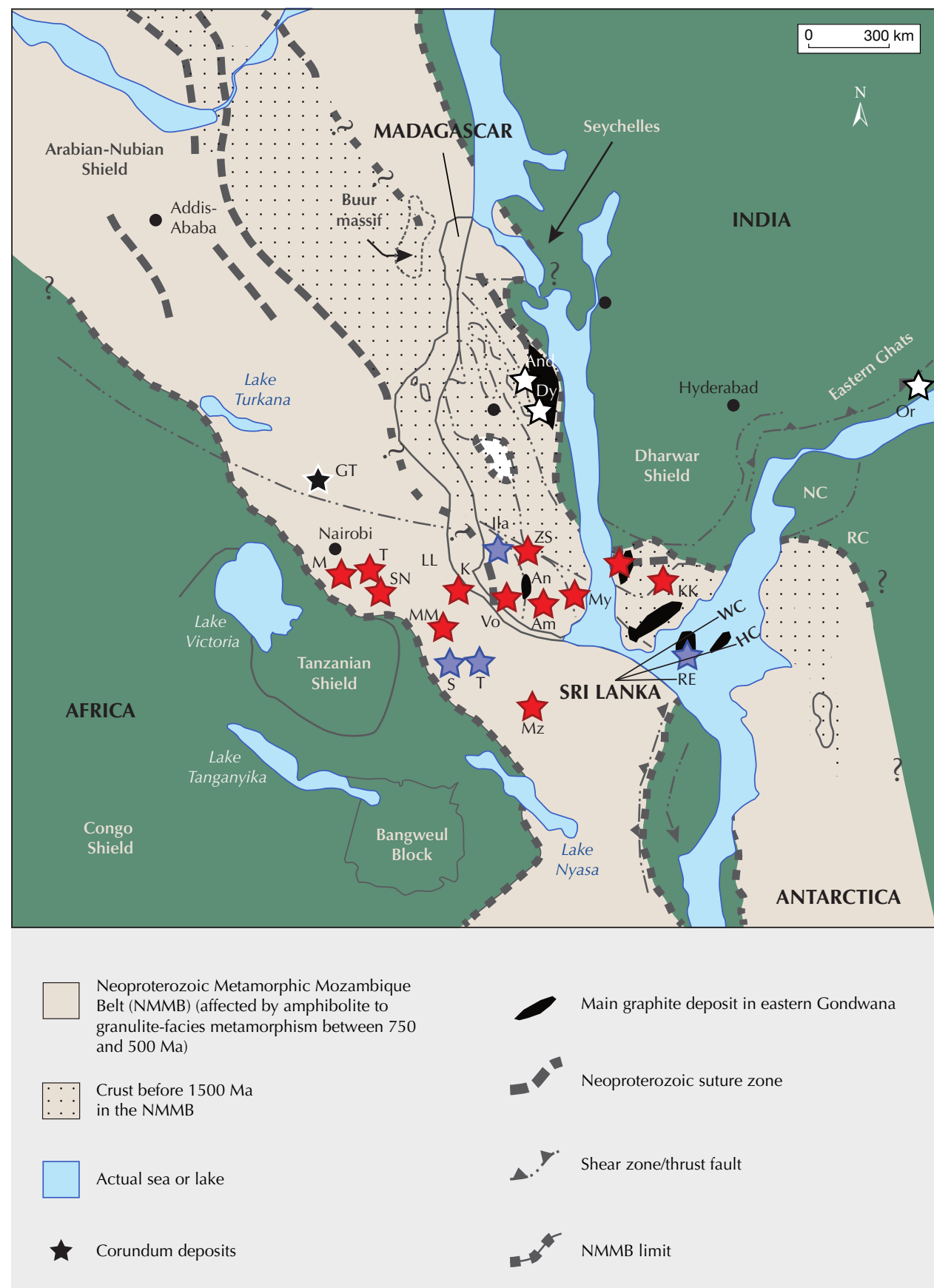

Figure 2. Juxtaposition of Antarctica, Sri Lanka, India, Madagascar, and Eastern Africa in a reconstruction of Gondwana showing the locations of the main gem corundum deposits (see Giuliani et al., 2014). Eastern Africa: Garba Tula (GT), Mangare (M), Twiga (T), Si Ndoto (SN), Longido and Lonsogonoi $(L L)$, Mahenge and Morogoro (MM), Kalalani and Umba (K), Songea (S), Tunduru (T). Mozambique: Montepuez (Mz); Madagascar: Ilakaka (Ila), Zazafotsy and Sahambano (ZS), deposits from the Vohibory region (Vo), Ambatomena (Am), Andranondambo (An), Andilamena (And), Didy (Dy). South India: Mysore (My),

Karur-Kangayam corundum belt (KK), Orissa (Or). Sri Lanka: Ratnapura and Elahera (RE), Wanni Complex (WC), Highland Complex (HC). Antarctica: Napier Complex (NC), Rayner Complex (RC), Lützow-Holm Complex (LHC), Yamoto-Belgique Complex (YBC). zoic (65 Ma to Quaternary). Gem corundum occurs worldwide as xenocrysts or megacrysts in xenoliths or enclaves incorporated in basaltic magmas during their ascent. Such sapphire and ruby deposits occur from Tasmania through eastern Australia, Southeast Asia, and eastern China to far eastern Russia (Graham et al., 2008). They are also found in Nigeria and Cameroon in the Air and Hoggar regions; the French Massif Central in the Limagne Rift; in northern, central, and eastern Madagascar (Hughes, 1997; Giuliani et al., 2014); and recently at Aksum in Ethiopia (Vertriest et al., 2019).

Classification of Corundum Deposits. Classification systems have evolved over time and are based on different mineralogical and geological features:

1. the morphology of corundum (Ozerov, 1945)

2. the geological context of the deposits (Hughes, 1997) 


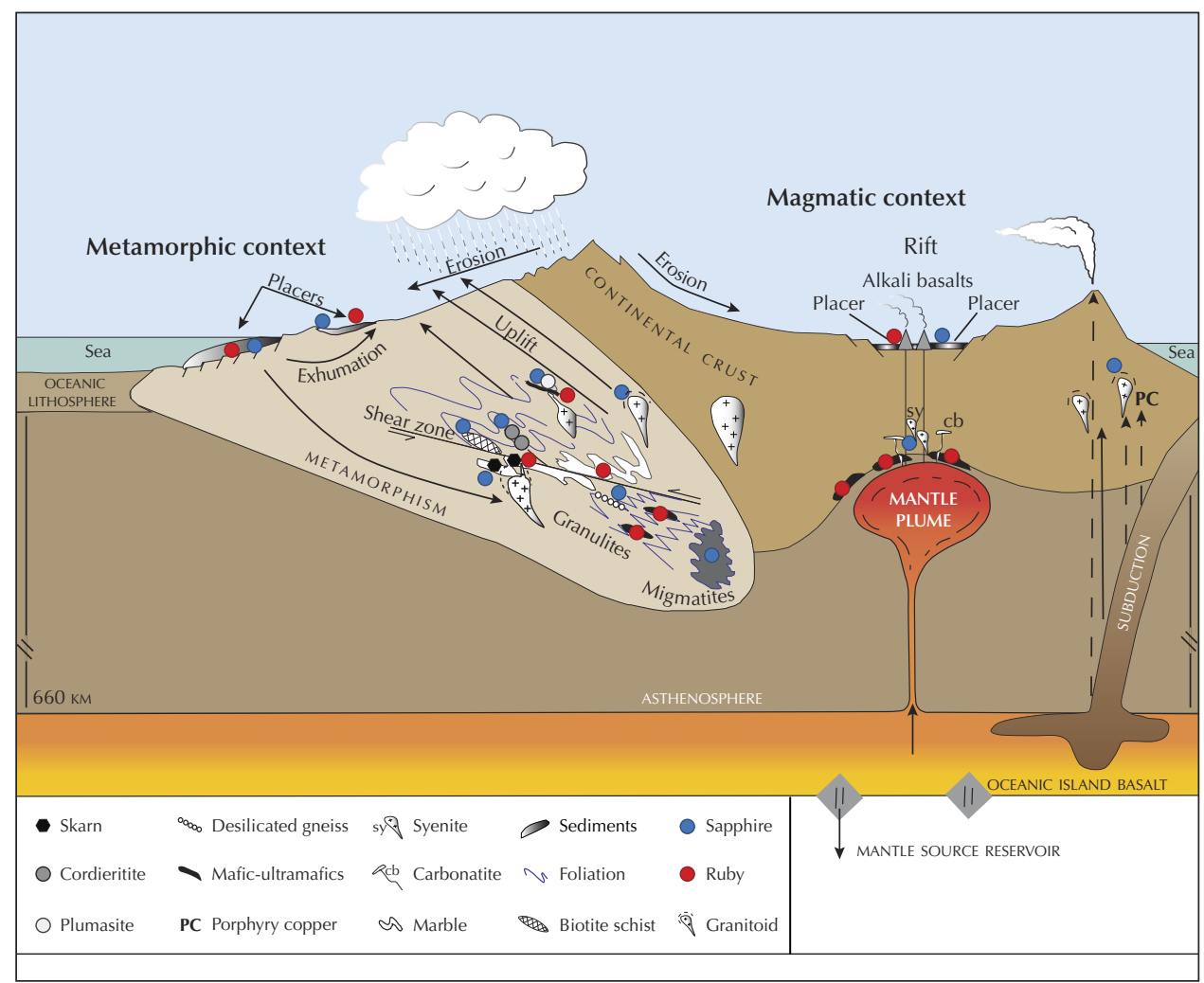

Figure 3. The different types of corundum deposits in their geological and geodynamical environments. The vertical dimension is not to scale, and the subcontinental lithosphere is not shown. Modified from Giuliani et al. (2014).

3. the lithology of the host rocks (Schwarz, 1998)

4. the genetic processes responsible for corundum formation (Simonet et al., 2008)

5. the genetic type of the deposit (Kievlenko, 20031

6. the geological environment and nature of the corundum host rock (Garnier et al., 2004; Giuliani et al., 2007a, 2014)

7. the oxygen isotopic composition of the corundum (Giuliani et al., 2012)

Today, gem corundum deposits are classified as primary and secondary deposits. Primary deposits contain corundum either in the rock where it crystallized or as xenocrysts and in xenoliths in the rock that carried it from the zone of crystallization in the crust or mantle to the earth's surface.

Primary deposits are subdivided into two types: magmatic and metamorphic (figure 3). Magmatic deposits include gem corundum in alkali basalts and sapphire in lamprophyres and syenites. Metamorphic deposits are divided into metamorphic deposits sensu stricto (marble; M-UMR), and metamorphicmetasomatic deposits characterized by high fluidrock interaction and metasomatism (i.e., plumasite or desilicated pegmatites in M-UMR and marble, skarn deposits, and shear zone-related deposits in different substrata, mainly corundum-bearing $\mathrm{Mg}$-Crbiotite schist).

Secondary deposits (i.e., present-day placers) are of two types (Dill, 2018). The first are eluvial concentrations derived by in situ weathering or weathering plus gravitational movement or accumulation. Eluvial-diluvial deposits are on slopes and in karst cavities (marble type). Colluvial deposits correspond to decomposed primary deposits that have moved vertically and laterally downslope as the hillside eroded. The second are alluvial deposits resulting from erosion of the host rock and transport of corundum by streams and rivers. Concentration occurs where water velocity drops at a slope change in the hydrographical profile of the river, such as at the base of a waterfall or in broad gullies, debris cones, meanders, and inflowing streams. Sometimes the corundum placers are marine, as at Nosy Be Island, Madagascar (Ramdhor and Milisenda, 2004).

Geology and Genesis of Primary Magmatic Corundum Deposits. Gem corundum in magmatic deposits is found in plutonic and volcanic rocks. In plutonic rocks, corundum is associated with rocks deficient in silica and their pegmatites, namely syen- 
ite (Simonet et al., 2004) and nepheline syenite (Sorokina et al., 2017b). The corundum formed by direct crystallization from the melt as an accessory mineral phase. In volcanic rocks, sapphire and occasionally ruby are found in continental alkali basalt (Sutherland et al., 1998a). The corundum occurs as xenocrysts in lava flows and plugs of subalkaline olivine basalts, high-alumina alkali basalt, and basanite. These magmas occur in crustal extensional environments impacted by the rise of upwelling mantle plumes. The sapphires are either blue-greenyellow (BGY; figure 4A) or pastel-colored, and the deposits have economic importance only because advanced weathering in tropical regions concentrates the sapphires in eluvial and especially large alluvial placers. Gem sapphires also occur as xenocrysts in alkaline basic lamprophyre such as for the Yogo Gulch deposit in Montana (Brownlow and Komorowski, 1988; Renfro et al., 2018), as mafic dikes of biotite monchiquite called ouachitite, a lamprophyre characterized by an abundance of phlogopite and brown amphibole, olivine, clinopyroxene, and analcime. For other Montana deposits such as Missouri River, the lamprophyres have not been identified and Berg and Palke (2016) found sapphires in a basaltic trachyandesite sill. Berg (2007) postulated that the Rock Creek sapphires were transported by rhyolitic volcanism.
Research over the last decade has greatly improved our knowledge of the genesis of sapphire-bearing lamprophyres in Montana (Berg and Palke, 2016, Palke et al., 2016, 2017) and gem corundum-bearing alkali basalts (Graham et al., 2008; Sutherland et al., 2009; Uher et al., 2012; Baldwin et al., 2017; Palke et al., 2018). The sapphires and/or rubies are xenocrysts and more rarely megacrysts in xenoliths formed under metamorphic and/or magmatic conditions (figures 4B, D). Previous trace element chemistry of the alluvial sapphires from Montana suggested a metamorphic origin (Peucat et al., 2007). However, Palke et al. (2016) reported the presence of $\mathrm{Na}$ and Ca glassy melt inclusions in Yogo Gulch sapphires, which suggested a magmatic origin. That study related the formation of sapphire to partial lower crustal melting of plagioclase-rich magmatic rocks by the lamprophyre. In this scenario, the sapphires are not "accidental" xenocrysts originating elsewhere, but rather "in situ" xenocrysts enclaved by the lamprophyre itself before their transport to the surface (Palke et al., 2018).

Studies of the BGY sapphires and ruby in alkali basalts (figure 4) focused on solid inclusions (Sutherland et al., 2009; Baldwin et al., 2017; Palke et al. 2018), trace element geochemistry (Peucat et al., 2007), oxygen isotopes (Yui et al., 2003; Giuliani et al., 2005), and the nature of their parental xenoliths
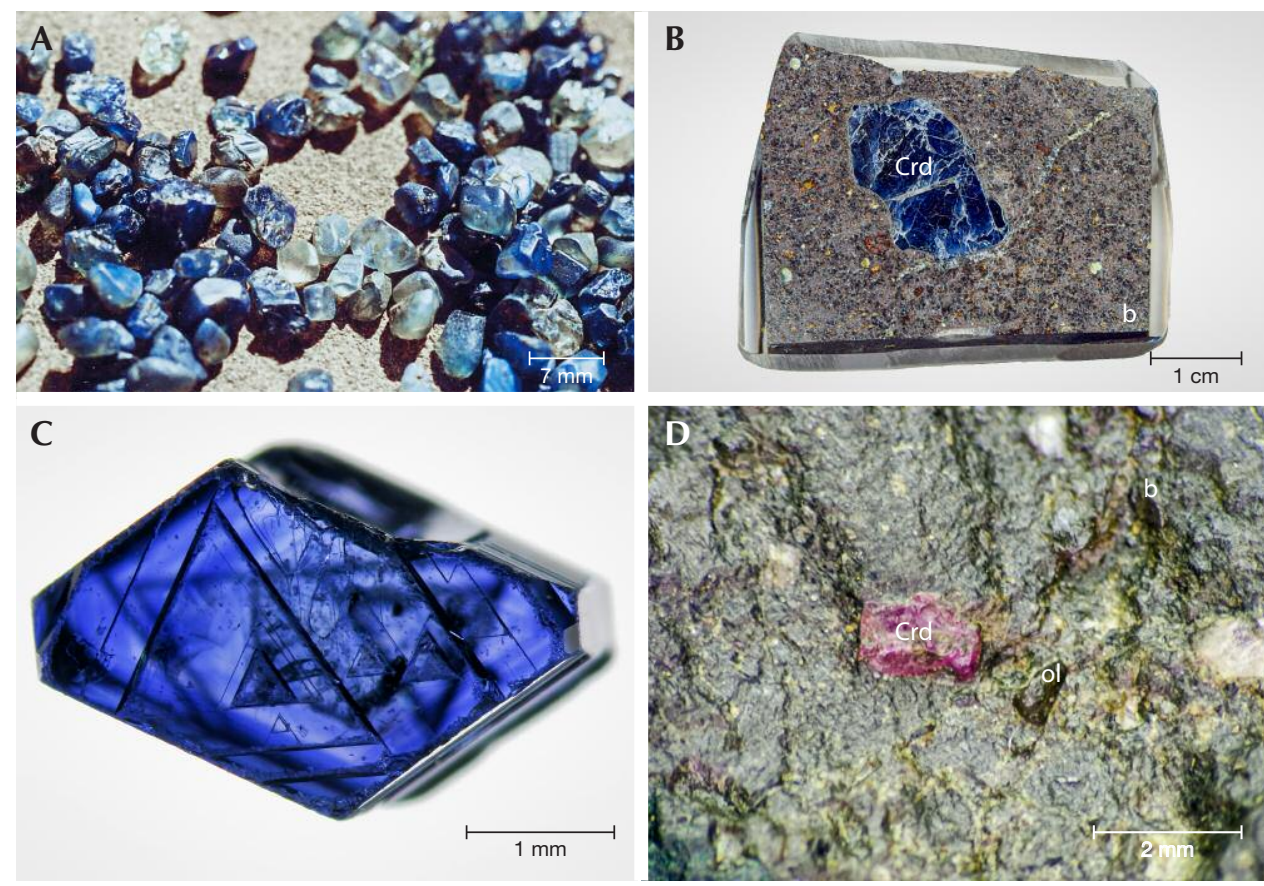

Figure 4. Gem corundum associated with alkali basalts. A: Blue-green-yellow sapphires from the Ambondromifehy placers, Antsiranana region, Madagascar; photo by G. Giuliani. B: Sapphire xenocryst (Crd) included in an alkali basalt (b) from the Changle deposit, China; photo by F. Fontan. $C$ : Sapphire from the Souliot placer in the Massif Central, France; photo by D. Schlaefli. D: Ruby (Crd) xenocryst in an alkali basalt (b) containing $a$ crystal of peridot (ol) from the Soamiakatra deposit in the Ankaratra Massif, central Madagascar; photo by S. Rakotosamizanany. 


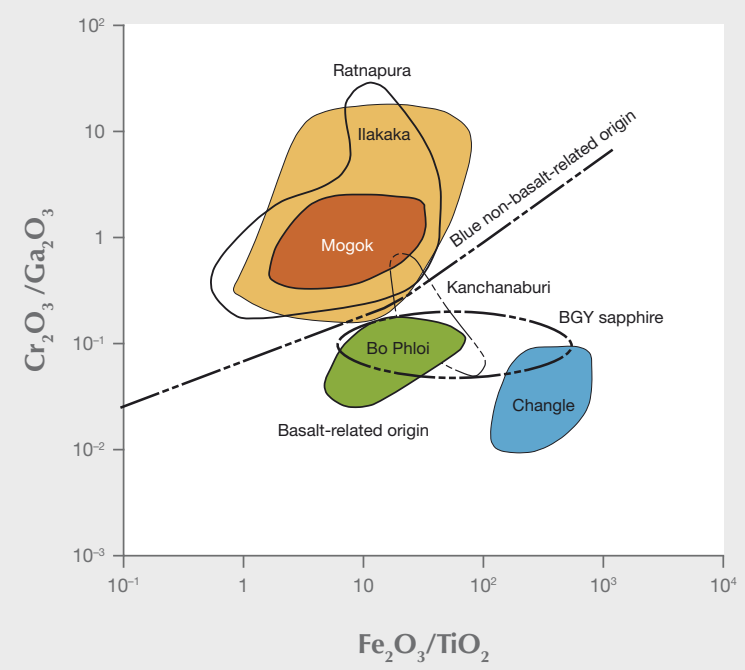

Figure 5. The $\mathrm{Fe}_{2} \mathrm{O}_{3} / \mathrm{TiO}_{2}$ vs. $\mathrm{Cr}_{2} \mathrm{O}_{3} / \mathrm{Ga}_{2} \mathrm{O}_{3}$ diagram used for geological discrimination between blue sapphires from metamorphic and basalt-related origins. The metamorphic gem sapphires originate from the placers of Ilakaka in Madagascar, Ratnapura in Sri Lanka, and Mogok in Myanmar. The magmatic sapphires are from the placers of Bo Phloi and Kanchanaburi in Thailand, and Changle in China. The chemical field of the BGY sapphires defined by Sutherland and Schwarz (2001) is also shown.

(Rakotozamizanany et al., 2014) to show that the gem corundum may have different magmatic and metamorphic origins.

Within a single gem province in Australia, variations in color observed for corundum found $\sim 10 \mathrm{~km}$ apart suggest the existence of multiple sources for the gemstones (Sutherland et al., 1998a; Sutherland and Schwarz, 2001). Studies of trace element distributions in corundum from New South Wales and Victoria found evidence for two contrasting geochemical fields, one for magmatic sapphire and one for metamorphic crystals. The same geochemical behavior was confirmed for corundum from the Kanchanaburi-Bo Rai and Nam Yuen deposits in Thailand and Pailin in Cambodia. The Fe/Ti vs. Cr/Ga chemical variation diagram proposed by Sutherland et al. (1998b) is commonly used to separate magmatic from metamorphic blue sapphires (figure 5). "Magmatic" corundum crystals have a $\mathrm{Cr}_{2} \mathrm{O}_{3} / \mathrm{Ga}_{2} \mathrm{O}_{3}$ ratio $<1$ and solid inclusions of Nb-bearing rutile, ilmenite, ferrocolumbite, ferrotantalite, pyrochlore, fersmite, samarskite, hercynite, magnetite, zircon, and iron oxides. "Metamorphic" corundum crystals have pastel (blue, pink, orange) to ruby color, are rich in chromium and poor in gallium $\left(\mathrm{Cr}_{2} \mathrm{O}_{3} / \mathrm{Ga}_{2} \mathrm{O}_{3}\right.$ ratio $\left.>3\right)$, and have chromiferous spinel, pleonaste, Al-rich diopside, and sapphirine inclusions.

Several hypotheses have been advanced to explain the formation of magmatic sapphires: crystallization from highly evolved melts, most likely syenites (Uher et al., 2012); partial melting of amphibole-bearing lithosphere (Sutherland et al., 1998b); reaction of a fractionated silicate melt with a carbonatitic melt (Guo et al., 1996); partial melting of Al-rich rocks of the crust (such as anorthosites; Palke et al., 2016, 2017); and a carbonatitic melt exsolved from highly evolved phonolites (Baldwin et al., 2017).

The origin of ruby is always debated, and its metamorphic origin is questioned once more by recent studies showing melt inclusions in ruby from the Chanthaburi-Trat region of Thailand and Pailin in Cambodia (Palke et al., 2018). Based on the chemical composition of these melt inclusions, the protolith of ruby is suggested to be an "anorthosite" that was converted at high pressure to a garnet-clinopyroxenite. In this scenario, the rubies are considered to be xenocrysts of their host basalts. Xenoliths of rubybearing garnet-clinopyroxenite were found in alkali basalt in the primary Soamiakatra deposit in Madagascar (Rakotosamizanany et al., 2014). The associations of clinopyroxene + pyrope + scapolite + ruby and spinel + ruby + pyrope indicated formation at $1100^{\circ} \mathrm{C}$ and 20 kilobars, at the limit of the eclogite domain, corresponding to depths of approximately 60 $\mathrm{km}$. The protolith of the garnet pyroxenite was proposed to be olivine-rich cumulates and/or plagioclase.

Geology and Genesis of Metamorphic Corundum Deposits. Corundum is a high-temperature mineral that forms naturally by metamorphism of aluminarich rocks under amphibolite and granulite facies conditions, and at temperatures between $500^{\circ}$ and $800^{\circ} \mathrm{C}$ (Simonet et al., 2008). Metamorphic gem corundum deposits are located in metamorphosed M-UMR, marble, quartzite, gneiss, and metapelite complexes that were heated either regionally or by thermal anomalies generated by local plutonic intrusions (figure 3). The various formation mechanisms depend on either isochemical metamorphism (i.e., regional metamorphism) or metasomatic metamorphism (i.e., contact and/or hydrothermal-infiltration processes affecting the lithology).

There are two main subtypes of metamorphic corundum deposits: (a) metamorphic deposits sensu 
stricto, such as corundum in marbles and M-UMR; and (b) metamorphic-metasomatic deposits related to fluid circulation in M-UMR and Ca-rich host rocks such as limestones, marbles, and gneiss.

Metamorphic Deposits Sensu Stricto. The first metamorphic deposit sensu stricto is defined by ruby in marble from Central and Southeast Asia. This is one of the main worldwide sources for high-quality ruby with intense "pigeon's blood" color and high transparency. These deposits occur in metamorphosed platform carbonates that are generally associated with marbles intercalated with gneisses that are sometimes intruded by granitoids (see Giuliani et al., 2014). The ruby mineralization is restricted to peculiar impure marble horizons. The protolith of the ruby-bearing metamorphic rocks is carbonates rich in detrital clays and organic matter and intercalated evaporitic layers. Ruby crystals occur:

1. Disseminated within marble and associated with phlogopite, muscovite, scapolite, margarite, spinel, titanite, pyrite, and graphite, as in Afghanistan (Jegdalek), Nepal (Chumar and Ruyil), Pakistan (Hunza Valley and Nangimali), Myanmar (Mogok and Mong Hsu), and Vietnam (Luc Yen, Quy Chau)

2. In veinlets or gash veins, as in some occurrences in northern Vietnam, associated with phlogopite, margarite, titanite, graphite, and pyrite, and sometimes related to micro-shear zones, as at Nangimali in Pakistan

3. In pockets associated with orthoclase, phlogopite, margarite, graphite, and pyrite in some occurrences in northern Vietnam.

The ruby formed during retrograde metamorphism at $\mathrm{T} \sim 620-670^{\circ} \mathrm{C}$ and $\mathrm{P} \sim 2.6-3.3$ kilobars (Garnier et al., 2008). The aluminum and the chromophore elements in the ruby originated from marbles (e.g., $\mathrm{Al}$ up to 1000 ppmw, $\mathrm{V}$ and $\mathrm{Cr}$ between 5 and $30 \mathrm{ppmw}$ in the marble of the Nangimali deposit). The nature and chemical compositions of the solid (anhydrite, Na-scapolite, F-paragonite, F-Na-phlogopite, F-pargasite) and fluid inclusions highlight the major contribution of evaporites during metamorphism of the initial protolith (Giuliani et al., 2015, 2018). Fluorine probably played an important role in the extraction of the aluminum present in the impurities (clays) in the limestone during metamorphism.

The second metamorphic deposit sensu stricto is related to ruby in metamorphosed M-UMR (gabbroic and dunitic rocks), which is also called amphibolitetype. The majority of rubies are produced in Africa, from deposits located in the Neoproterozoic-age metamorphic Mozambique Belt (750-540 Ma) that extends from Somalia through Kenya, Tanzania, Malawi, Mozambique, and Madagascar. This type of deposit is found worldwide, and new deposits have been discovered in Greenland at Aappaluttoq (Fagan, 2015, 2018) and Mozambique at Montepuez, Ruambeze, and M'sawize (Pardieu et al., 2009; Pardieu and Chauviré, 2013; Simonet, 2018). The most common assemblage of these deposits is corundum, anorthite, amphibole (gedrite, pargasite), and margarite. Other index minerals are sapphirine, garnet, spinel, kornerupine, phlogopite, and zoisite. The assemblage formed under amphibolite and granulite facies conditions at $\mathrm{P}=9-11.5$ kilobars and $\mathrm{T}=750-800^{\circ} \mathrm{C}$ for the ruby-bearing amphibolite in the Vohibory area of Madagascar (Nicollet, 1986), and $\mathrm{P}=7$ to 10 kilobars and $\mathrm{T}=800-850^{\circ} \mathrm{C}$ for those located at Buck Creek in North Carolina (Tenthorey et al., 1996).

At the Winza deposit in central Tanzania (Peretti et al., 2008; Schwarz et al., 2008), gem corundum crystals are embedded in dark amphibolite. The corundum is locally associated with areas of brown to orangy garnet \pm feldspar, with accessory Cr-spinel, mica, kyanite, and allanite. The ruby and sapphire crystals are closely associated with dikes of a garnet- and pargasite-bearing rock cross-cutting amphibolite (figure 6A). The central part of the dike is composed of garnet (pyropealmandine) + pargasite \pm plagioclase \pm corundum \pm spinel \pm apatite. Metamorphic conditions estimated from the garnet-amphibole-corundum equilibrium assemblage show that the metamorphic overprint occurred at $\mathrm{T} \sim 800 \pm 50^{\circ} \mathrm{C}$ and $\mathrm{P} \sim 8-10 \mathrm{kbar}$ (Schwarz et al., 2008). The chemical composition of Winza ruby and sapphires (figure 6B) includes moderate contents of $\mathrm{Cr}\left(0.1-0.8\right.$ wt. \% $\left.\mathrm{Cr}_{2} \mathrm{O}_{3}\right)$ and $\mathrm{Fe}(0.2-0.8$ wt.\% $\left.\mathrm{Fe}_{2} \mathrm{O}_{3}\right)$, very low to low amounts of $\mathrm{Ti}(55-192 \mathrm{ppmw}$ $\mathrm{TiO}_{2}$ ) and $\mathrm{V}$ (up to 164 ppmw $\mathrm{V}_{2} \mathrm{O}_{3}$ ), and low to moderate $\mathrm{Ga}\left(64-146\right.$ ppmw $\left.\mathrm{Ga}_{2} \mathrm{O}_{3}\right)$.

The gem corundum deposits of southwest Greenland are another example of ruby hosted in gabbroic rocks subjected to metamorphic metasomatism (Fagan, 2018). The geology of the Aappaluttoq deposit is dominated by an intrusive gabbro to leucogabbro sequence of rocks with significant volumes of ultramafic rocks in the Fiskenæsset Complex, a layeredcumulate igneous complex. The intrusive suite comprises layers of gabbro, ultramafic rocks, leucogabbro, and calcic anorthosite. The corundum mineralization occurs in a specific stratigraphic horizon 

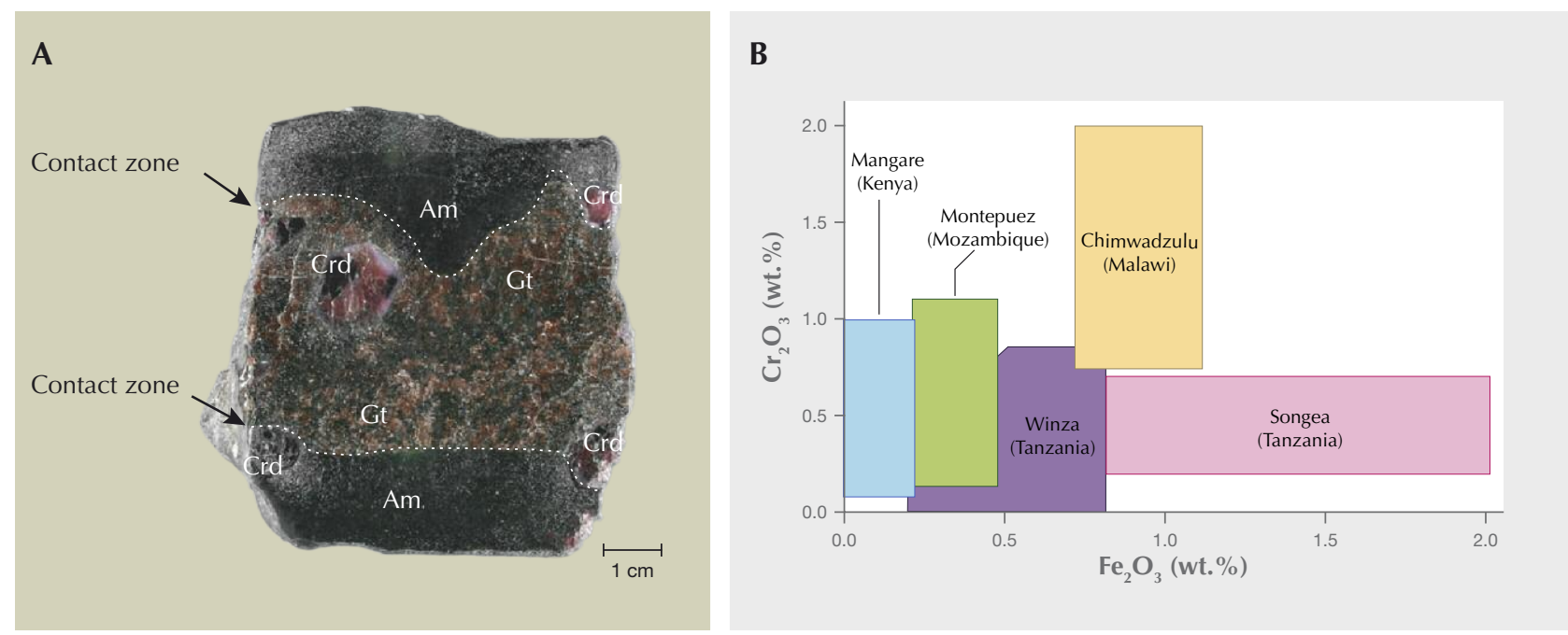

Figure 6. A: The primary ruby and sapphire mineralization at the Winza deposit in Tanzania is hosted by an orangy brown garnet-rich rock (Gt) intercalated in a fine-grained amphibolite (Am). B: $\mathrm{Fe}_{2} \mathrm{O}_{3} v \mathrm{vs} \mathrm{Cr}_{2} \mathrm{O}_{3}$ diagram showing the chemical composition of the Winza rubies compared with those from other ruby deposits hosted in mafic-ultramafic rocks, such as Chimwadzulu (Malawi), Mangare (Kenya), Montepuez (Mozambique), and the placer at Songea (Tanzania). Photo by P. Lagrange.

in the metamorphic complex; this probably represents a unit with high $\mathrm{Al}$, low $\mathrm{Si}$, and a high fluid flux. The ruby lies between layers of ultramafic rock and leucocratic gabbro. The main corundum-bearing ore is composed of three main rock types (figure 7): sapphirine-gedrite, leucogabbro, and a phlogopitite, which is the most important. The leucogabbro contains a large amount of pink corundum. The gabbro is rich in $\mathrm{Al}$ and is believed to be the unit responsible for releasing the $\mathrm{Al}$ to form the corundum. Its structural location, distal from the ultramafic unit, is thought to be responsible for the lack of ruby, as the Cr geochemical gradient was not sufficient to enrich the corundum within the gabbroic units enough to impart more than a pink coloration. The phlogopitite is the host for the majority of the ruby at Aappaluttoq. This is due to the proximity of this unit to the ultramafic Cr source rock, reflecting the relative mobility of $\mathrm{Cr}$ in a fluid-rich environment. This unit is ultimately a metasomatic product, comprising approximately $90 \%$ phlogopite, $5 \%$ biotite, and $5 \%$ corundum.

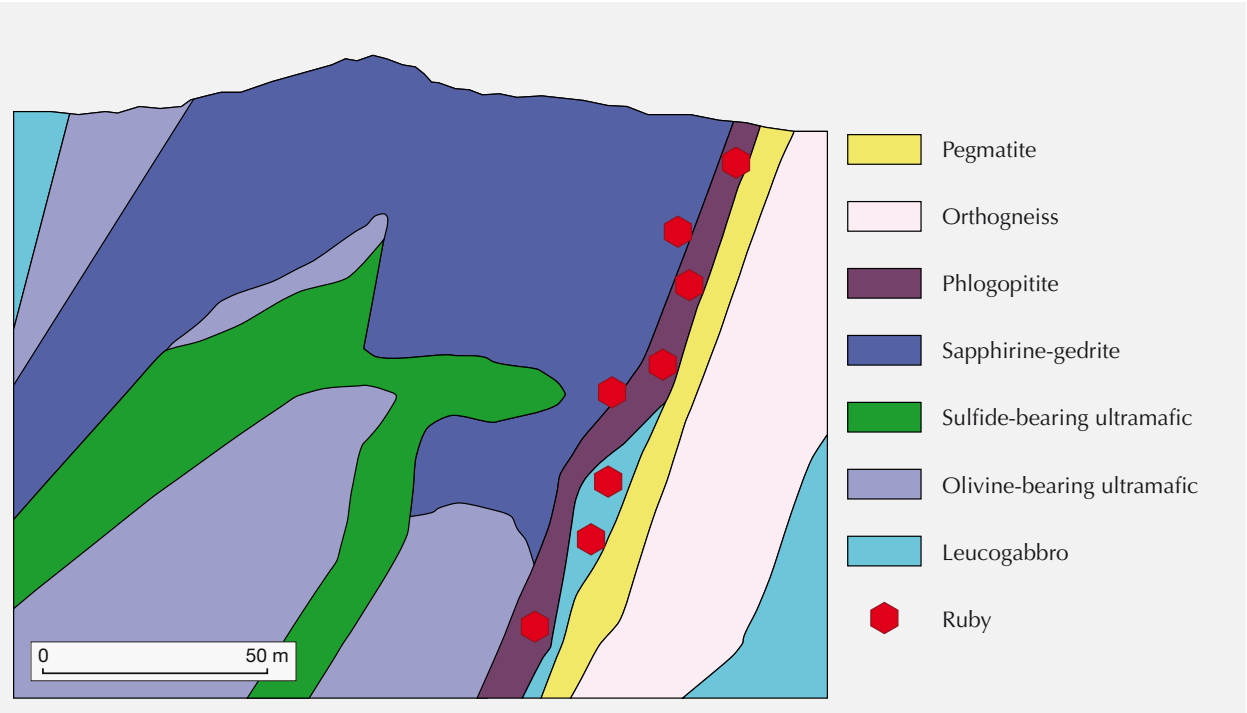

Figure 7. Schematic cross section of the ruby deposit at Aappaluttoq, in the Fiskenæsset district, Greenland. The ruby mineralization is hosted by phlogopitites, phlogopitized leucogabbro, and sapphirine-gedrite-bearing rocks. Modified from Fagan (2018). 
Metamorphic-Metasomatic Deposits. Here, two main subtypes are distinguished: The first subtype corresponds to desilicated pegmatite in mafic rocks (i.e., plumasites). These deposits formed at medium to high temperatures during hydrothermal fluid circulation and metasomatism that developed at the contact of two contrasting lithologies: (1) granite or pegmatite adjoining (2) M-UMR, marble, or gneiss (figure 8A). The metasomatic reactions are related to the infiltration of post-magmatic solutions, which originated from the same granite or from other magmatic or metamorphic events. The mechanism of desilication, a loss of quartz, involves diffusion of Si from a pegmatite vein to an ultramafic rock (which plays the role of $\mathrm{SiO}_{2}$ sink) at a rate more rapid than the diffusion of $\mathrm{Al}$. The Al:Si ratio increases in the pegmatite vein, and a metasomatic plagioclase-corundum association in which the mass of alumina per unit volume is much greater than in the initial rock may develop if the volume of rock decreases at the same time and is underlain by a zone of quartz dissolution.

World-class sapphire deposits in desilicated pegmatites have been described from the Umba River (Solesbury, 1967) and Kalalani (Seifert and Hyršl, 1999) in Tanzania; the Sumjam deposit in Kashmir (Lydekker, 1883); the Mangare area in southern Kenya, including the well-known John Saul mine (Mercier et al., 1999; Simonet, 2000); and the Polar Urals in Russia (Meng et al., 2018).

The states of Jammu and Kashmir produce the blue sapphires most prized for their gorgeous blue color and velvety luster, caused by layers of microscopic liquid inclusions. The deposit is located in Cambrian metamorphic rocks showing a succession of marble, amphibolite, and gneiss that have been intruded by pegmatites (Atkinson and Kothavala, 1983). The sapphire is associated with pockets or lenses of olivine-talc-spinel-bearing metamorphic rocks. The lenses are from 1 to 100 meters in length and up to 30 meters thick and enveloped by a green aureole of tremolite, actinolite, and anthophyllitebearing rocks. Desilicated pegmatites are located at the contact between the lenses and the amphibolite. The mineralogical association consists of plagioclase, mica, tourmaline, and sapphire. The rims of the desilicated pegmatite are composed of talc-biotite-carbonate and tourmaline-bearing rocks (Peretti et al., 1990). Study of the primary carbonic fluid inclusions in the sapphire has indicated fluctuation of the conditions of fluid trapping in the crystals: $\mathrm{P} \sim 3.7-5.6$ kbar and $\mathrm{T} \sim 680-700^{\circ} \mathrm{C}$ at the center, and $\mathrm{P} \sim 2.9-$ $3.1 \mathrm{kbar}$ and $\mathrm{T} \sim 500^{\circ} \mathrm{C}$ at the periphery.
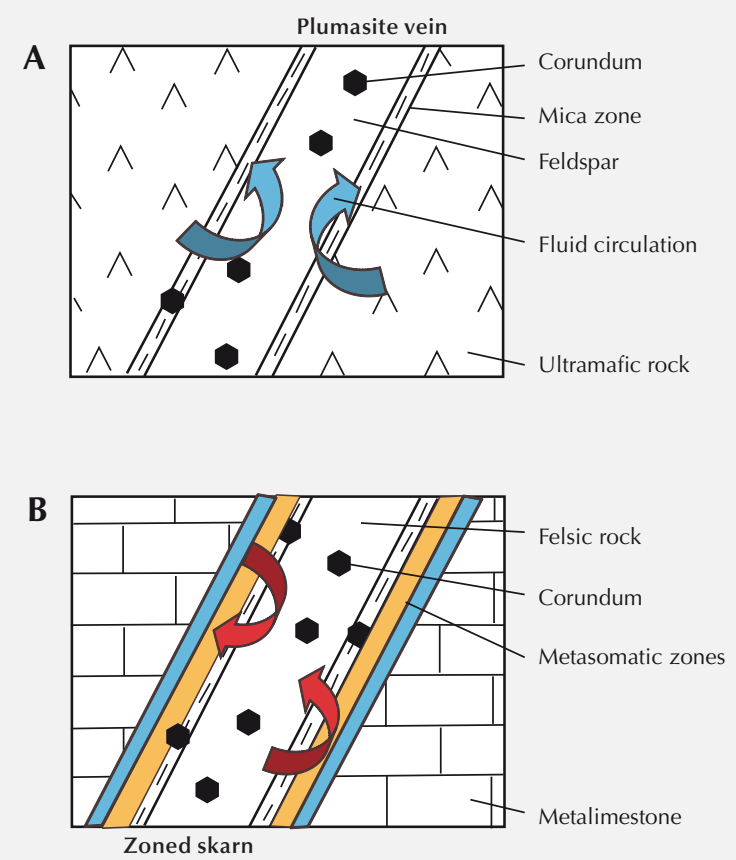

Figure 8. The formation of corundum in plumasite and skarn deposits by fluid-rock interaction. A: The metasomatic fluid circulated along the contact between two rocks of contrasting lithology, such as ultramafic or marble and pegmatite. The percolation inside the rocks induced metasomatic desilication of the silica-rich rocks and the formation of metasomatic rocks such as corundum-bearing plagioclase (plumasite), and/or phyllosilicate-rich rocks (phlogopite schist, vermiculite schist, chloritite). B: The skarn deposit is formed by a succession of different zoned rocks composed of Ca-rich silicates from the pegmatite to the Ca-rich host rock. Modified from Simonet et al. (2008).

The second metamorphic subtype deposit is formed by skarn deposits formed in marble or calcsilicate rocks. Skarns generally form when granitic intrusions (or equivalents) intrude Ca-bearing rocks such as pure or impure marbles (figure $8 \mathrm{~B}$ ). The deposits are associated with thermal metamorphism due to the temperature gradient around the intrusion. Every post-magmatic process linked to the emplacement of the pluton has a stage at which the solutions became acid, constituting a source of strong reactions with their wall rocks. As the activity of $\mathrm{K}, \mathrm{Na}$, and $\mathrm{Al}$ increases, these elements enter into reactions with marble or dolomitic marble, increasing the concentrations of $\mathrm{Ca}$ and $\mathrm{Mg}$ in solution. 
Such reactions produce feldspar, biotite, and Ca-bearing minerals. The association of Ca-bearing, usually Fe-rich silicates (including amphibole, pyroxene, garnet, epidote, and zoisite) or Mg-rich silicates (such as phlogopite, diopside, pargasite, and forsterite) defines the so-called skarn mineralogy.

World-class sapphire-bearing skarn deposits occur at Andranondambo in the Tranomaro area of southern Madagascar (Rakotondrazafy et al., 1996, 2008); at Thammannawa, near Kataragama in southeastern Sri Lanka (Dharmaratne et al., 2012); and at Bakamuna in the Elahera area of Sri Linka (Silva and Siriwardena, 1988).

Geology and Genesis of Secondary Corundum Deposits. Climate is the major factor in the formation of secondary deposits. In tropical areas, rocks are exposed to meteoric alteration, resulting in an assemblage of clay minerals, iron and manganese oxides, and other supergene phases. Corundum and zircon are resistant minerals found in soils, laterite, and gravelly levels overlying bedrock.

Of particular importance are paleoplacers characterized by different mineral phases cemented in a carbonate or silica-rich matrix. Paleoplacers of corundum are known from alkali basalt deposits in Madagascar. In Antsiranana Province, the paleoplacer is composed of a carbonate-karst breccia in cavities in Jurassic limestone (Schwarz et al., 2000; Giuliani et al., 2007b). In the Vatomandry area, the paleoplacer is a sandstone that contains hematite, ruby, sapphire, and zircon. At Ilakaka, gem corundum is found in three gravel levels in two main alluvial terraces deposited on Isalo sandstone. The terraces are weakly consolidated, but correspond to paleoplacers (Garnier et al., 2004). The Ilakaka deposits produce very fine blue, blue-violet, violet, purple, orange, yellow, and translucent sapphire crystals along with pink and red corundum, zircon, alexandrite, topaz, garnet, spinel, andalusite, and tourmaline.

Important placers formed in marble environments are found in Myanmar, where gem-bearing levels enriched in pebbles, sand, silt, clay, and iron oxides are called "byon" (Kane and Kammerling, 1992). The gem content is closely related to the formation of karst and chemical weathering of marble and associated rocks. The corundum is trapped in eluvial, colluvial, alluvial, fracture-filling, and cave deposits.

In Australia, sapphire and ruby in alkali basalts are subjected to a tropical climate, probably more so in the past. The resulting alluvial deposits are in eastern Australia, primarily northern New South Wales and central Queensland (Sutherland and Abduriyim, 2009). The main ruby production has been from Barrington Tops, Yarrowitch, and Tumbarumba, all in New South Wales. The sapphire-bearing basaltic sediments, locally called "wash," occur in layers 1 to 3 $\mathrm{m}$ thick underneath dark clayey soil some 1 to $3 \mathrm{~m}$ below the surface (Abduriyim et al., 2012). In the Inverell district of New South Wales, at the Mary Anne Gully mine, brown basaltic sedimentary soils are extracted from an area of 10 to $40 \mathrm{~km}^{2}$, and large-scale mining operations take place at Kings Plains.

At Montepuez in Mozambique, the main source of facet-grade material in the Gemfields properties is secondary deposits (SRK Consulting, 2015; Simonet, 2018). The secondary deposits are mainly colluvials with limited horizontal transport (more subangular fragments) and a few alluvial pebbles (smooth and round appearance). Most of the mineralized horizons are stone lines, weathering-resistant rock fragments formed by millions of years of erosion (Simonet, 2018). Composed of angular fragments of quartz and pegmatite, the stone lines are excellent traps for smaller grains of high-density minerals such as ruby. The colluvial deposits are either associated with the proximal primary deposits (as in the Maninge Nice/Glass mines) or are disconnected (as in the Mugloto mine).

\section{PART II: EMERALD}

Emerald is the green gem variety of beryl $\left(\mathrm{Be}^{2+}{ }_{3} \mathrm{Al}^{3+}{ }_{2} \mathrm{Si}^{4+}{ }_{6} \mathrm{O}^{2-}{ }_{18}\right)$ (figure 9). The color of emerald is due to trace amounts of $\mathrm{Cr}$ and/or $\mathrm{V}$ replacing $\mathrm{Al}$ in the crystal structure. Beryl has a hardness of 7.5-8 on the Mohs scale.

Economic Significance. Emerald is generally the third most valuable gem after diamond and ruby. The pricing of emeralds is unique in the colored gemstone market, emphasizing color almost to the exclusion of clarity, brilliance, or other characteristics (Walton, 2004).

The highest per-carat price ever paid for an emerald was $\$ 304,878$ per carat, at a total price of US $\$ 5,511,500$, for the Rockefeller ring at Christie's New York in June 2017. However, Elizabeth Taylor's Bulgari emerald still holds the record for the highest total price ever paid for an emerald at $\$ 6,130,500$, or $\$ 281,329$ per carat at 23.46 carats. An exceptional 10.11 ct Colombian faceted stone brought US\$1,149,850 in 2000 (Zachovay, 2002). In October 2017, a Gemfields auction of Zambian emeralds gen- 


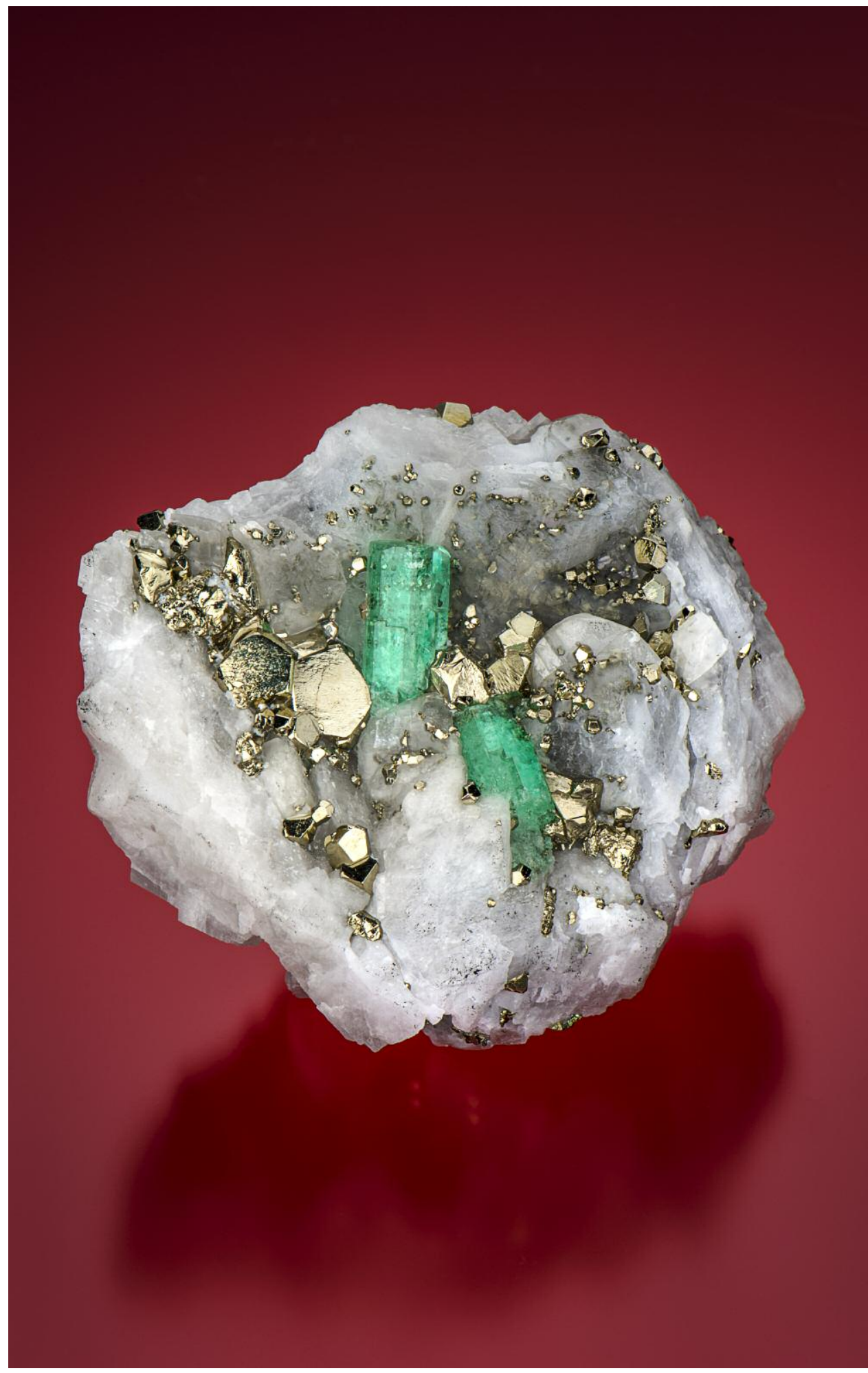

Figure 9. Emerald specimen from Chivor,

Colombia. The carbonate matrix presents a vug with emerald, and pyrite. The top emerald measures $16.82 \times 8.55$ $\mathrm{mm}$, the bottom emerald $11.98 \times 7.96 \mathrm{~mm}$.

The specimen measures $76.43 \times 63.44 \mathrm{~mm}$.

Photo by Robert Weldon/GIA; courtesy of Greg Turner, Cornerstone Minerals.

erated revenues of $\$ 21.5$ million ("In the News...," 2018 ); the average value of the bids was $\$ 66.21$ per carat (Branstrator, 2017). The auction included the 6,100 ct Insofu ("baby elephant") rough emerald from the Kagem mine. One year later Kagem produced another giant crystal, the 5,565 ct Inkalamu ("lion elephant") rough emerald (Gemfields, 2018). Giant crystals have also been discovered in Colombia, such 
as El Monstro $(16,020 \mathrm{ct})$ and the Emilia $(7,025 \mathrm{ct})$, both from the Gachalá region. In 2017, a large piece of biotite schist with several large emerald crystals was discovered in the Carnaíba mine, Brazil. The specimen, named Bahia, weighs $341 \mathrm{~kg}$, but the weight and value of the emeralds are unconfirmed (Weil, 2017).

Production. As with most gem materials, it is difficult to obtain accurate statistics for emerald production. In 2005, Colombia, Brazil, Zambia, Russia, Zimbabwe, Madagascar, Pakistan, and Afghanistan were the main producers (Yager et al., 2008). Today, the list of leading emerald producers is unchanged, with Colombia, Brazil and Zambia, at the top.

The original Colombian deposits are almost exhausted, despite Furagems' announcement of an estimated 3 million tons inferred emerald at a grade of 2 carats per ton for the Coscuez mine. Nevertheless, new finds in the Maripi area, beginning with La Pita in 1998 and then Las Cunas, should ensure that Colombia remains the most important source for years to come.

Brazil became a significant emerald producer during the 1970s, and by the end of the century it was exporting $\$ 50$ million annually (Lucas, 2012) and accounting for approximately $10 \%$ of global production (Schwarz and Giuliani, 2002). Although Brazilian emeralds were not traditionally known for their quality (Lucas, 2012), stones from the Itabira/Nova Era belt (which includes the highly productive Belmont mine) reportedly sell for up to $\$ 30,000$ per carat. Today, the main Brazilian production is related to emerald deposits associated with granitic intrusions in the states of Minas Gerais (74\%), Bahia (22\%), and Goiás (4\%) (Martins, 2018).

The Kafubu mining district in Zambia accounts for most of that country's production. The mining licenses at Kafubu extend for approximately $15 \mathrm{~km}$ of strike length. The development of modern mining on this large scale by Gemfields, through underground and huge opencast mining, allows for large quantities of high-quality commercial-grade gems.

Other important producers are Russia, from the Izumrudnye Kopi district approximately $60 \mathrm{~km}$ northeast of Ekaterinburg in the Ural Mountains (Grundmann and Giuliani, 2002), and Zimbabwe, from the Sandawana (formerly Zeus) mine approximately $360 \mathrm{~km}$ south of Harare.

As with other colored stones, emerald deposits are often located in countries with unstable political regimes without strong mineral rights security, and smuggling tends to be rampant. Despite these problems, emerald remains one of the most sought-after colored gemstones.

The Geochemistry of $\mathrm{Be}, \mathrm{Cr}$, and $\mathrm{V}$. Beryl is relatively rare because there is very little $\mathrm{Be}(2.1 \mathrm{ppmw})$ in the upper continental crust (Rudnick and Gao, 2003). Beryllium tends to be concentrated in rocks of the continental crust, such as granite, pegmatite, black shale, and their metamorphic equivalents. Chromium and V are more common 192 and 97 ppmw, respectively) in the upper continental crust (Rudnick and Gao, 2003) and are concentrated in dunite, peridotite, and basalt of the oceanic crust and upper mantle, and their metamorphic equivalents. However, high concentrations can also occur in sedimentary rocks, particularly black shale (Schwarz et al., 2002).

Unusual geologic and geochemical conditions are required for $\mathrm{Be}$ and $\mathrm{Cr}$ and/or $\mathrm{V}$ to meet. In the classic model, Be-bearing pegmatites interact with Cr-bearing M-UMR. However, in the Colombian deposits (see below) there is no evidence of magmatic activity, and it has been demonstrated that fluid circulation processes within the host black shale were sufficient to form emerald. In addition, researchers recognize that regional metamorphism and tectonometamorphic processes such as shear zone formation may play a significant role in certain deposits (e.g., Grundmann and Morteani, 1989, 1993; Cheilletz et al., 2001; Vapnik et al., 2005, 2006). Emeralds, though exceedingly rare, can obviously form in a wider variety of geological environments than previously thought (Walton, 2004).

Classification. Emerald deposits are found on all five continents (figure 10) and range in age from Archean (2.97 Ga for the Gravelotte deposit in South Africa) to Cenozoic (9 Ma for the Khaltaro deposit in Pakistan) (figure 11). Giuliani et al. (2019) introduced a new classification scheme in which emerald deposits are divided into two main types depending on the geological environment, and further subdivided on the basis of host rock (table 1):

Type I: Tectonic-magmatic-related, with subtypes hosted in:

IA. Mafic-ultramafic rocks (Brazil, Zambia, Russia, and others)

IB. Sedimentary rocks (China, Canada, Norway, Kazakhstan, Australia)

IC. Granitic rocks (Nigeria) 


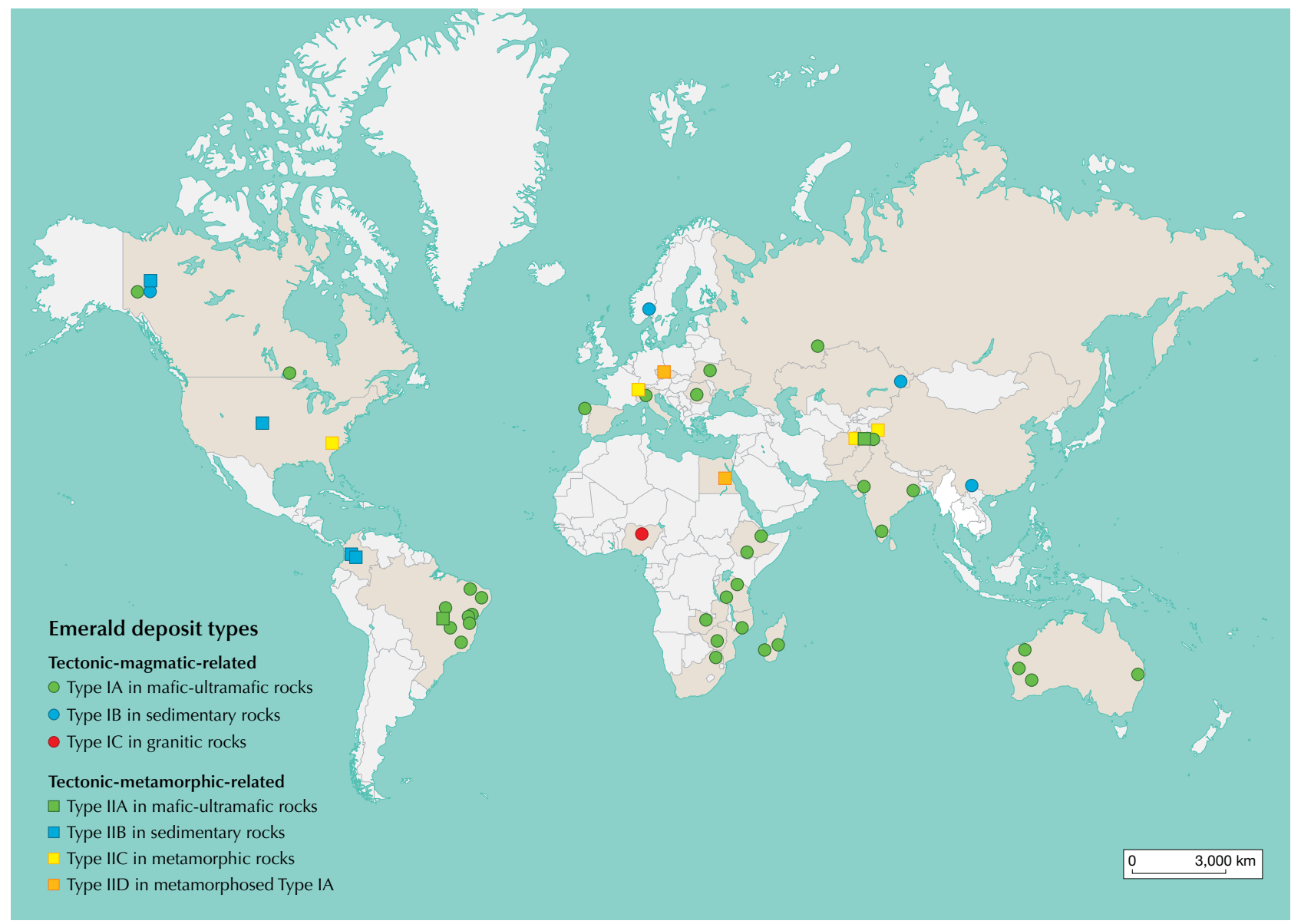

Figure 10. Map of emerald deposits and occurrences worldwide, divided into types and subtypes.

Type II: Tectonic-metamorphic-related, with subtypes hosted in:

IIA. M-UMR (Brazil, Austria)

IIB. Sedimentary rocks: black shale (Colombia, Canada)

IIC. Metamorphic rocks (China, Afghanistan, United States)

IID. Metamorphosed Type I deposits or hiddengranitic intrusion-related (Austria, Egypt, Australia, Pakistan) and some unclassified deposits

An idealized Type IA deposit is shown in figure 12. Type IA deposits are typified by the prolific emerald mines of central Zambia, of which Kagem is thought to be the world's largest open-pit mine for colored gemstones (Behling and Wilson, 2010). The emerald deposits are hosted by Cr-rich $(3,000$ to 4,000 ppmw) talc-chlorite \pm actinolite \pm magnetite metabasic rocks of the Muva Supergroup, which have been identified as metamorphosed komatiite (Seifert et al., 2004). The metabasite horizons are overlapped by a major field of Be-bearing pegmatite and hydrothermal veins $\sim 10 \mathrm{~km}$ in length that was emplaced during the late stages of the Pan-African orogeny ( $530 \mathrm{Ma}$; John et al., 2004). Economic emerald concentrations are almost entirely restricted to phlogopite reaction zones (typically 0.5 to $3 \mathrm{~m}$ wide) between quartz-tourmaline veins and metabasite (Zwaan et al., 2005). Chemical analyses (Siefert et al., 2004) indicate that the formation of phlogopite schist from metabasite involved the introduction of $\mathrm{K}_{2} \mathrm{O} / 8$ to 10 wt. \%), $\mathrm{F}(2.7$ to 4.7 wt. $\%), \mathrm{Li}_{2} \mathrm{O}$ (0.1 to 0.7 wt. $\%$ ), Rb (1,700 to 3,000 ppmw), Be (up to 1,600 ppmw), $\mathrm{Nb}$ (10 to $56 \mathrm{ppmw})$, and significant amounts of B. A fluid inclusion study suggested that the veins associated with emerald mineralization formed at $350^{\circ}$ to $450^{\circ} \mathrm{C}$ and 150 to 450 kilobars (Zachariáš et al., 2005). K-Ar dating of muscovite from a pegmatite and an associated quartz-tourmaline vein gave cooling ages of 452 to $447 \mathrm{Ma}$, which is considered to approximately date the emerald mineralization (Seifert et al., 2004). 
TABLE 1. Classification of emerald deposits (from Giuliani et al., 2019).

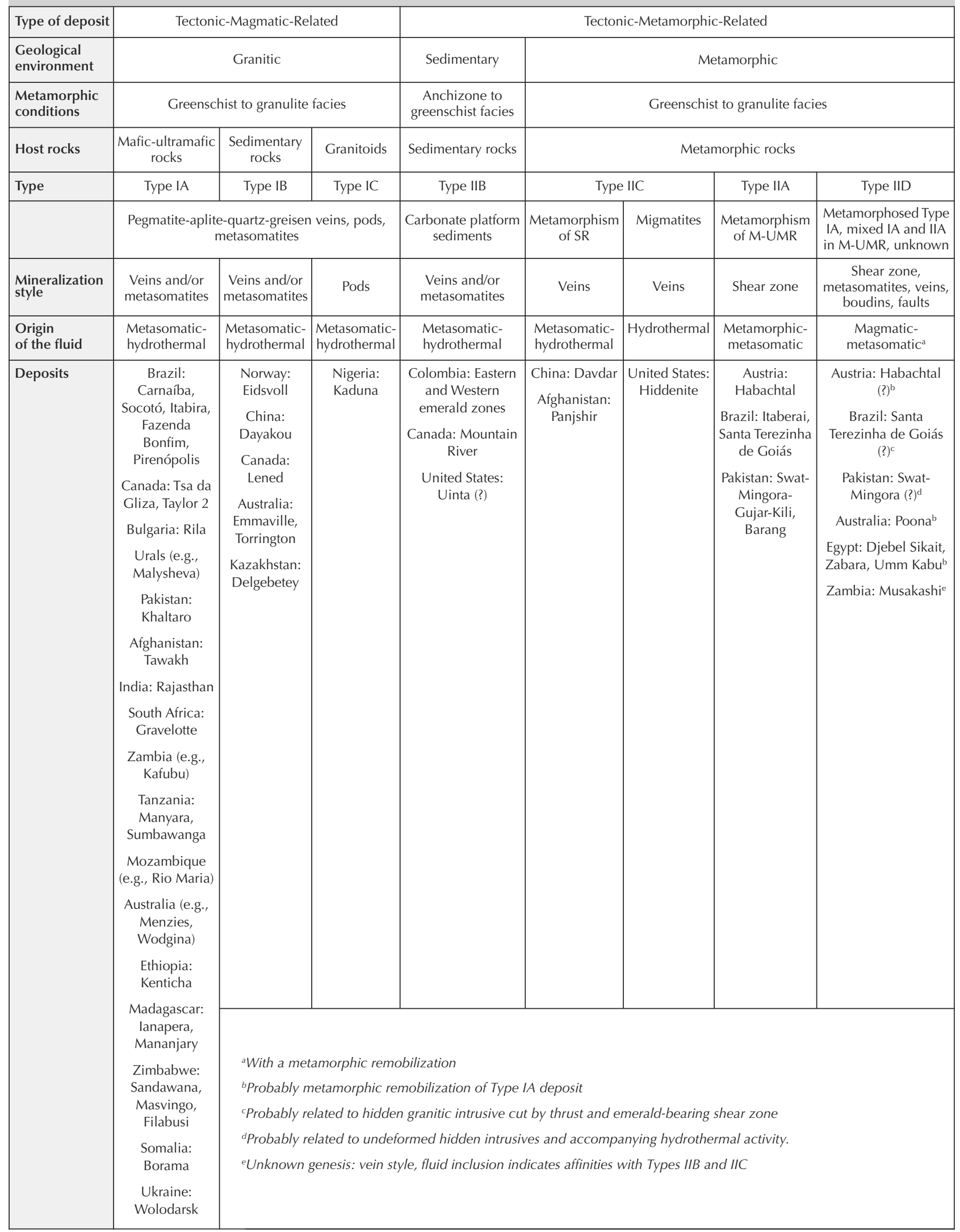




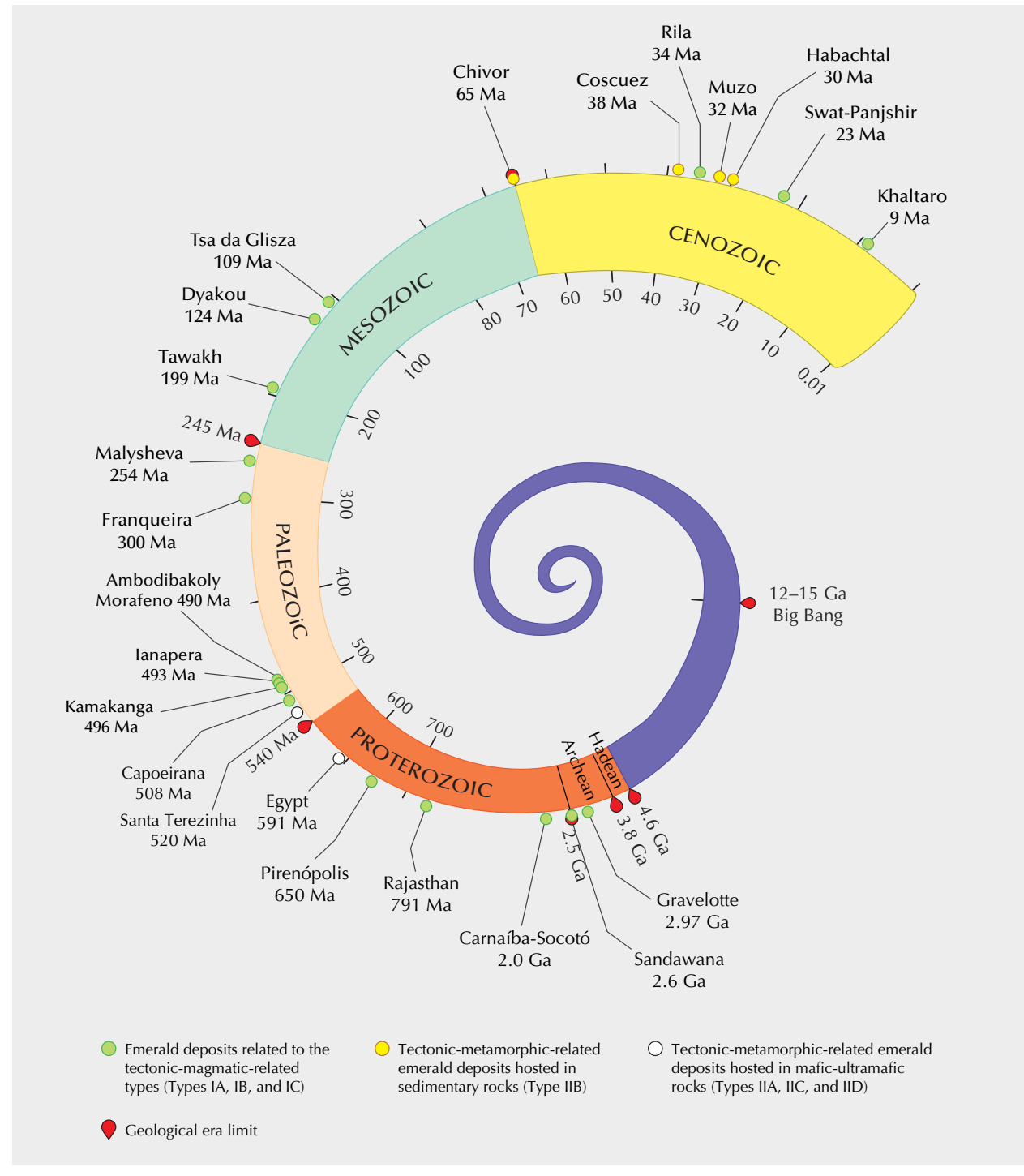

Figure 11. Spiral time diagram for emerald deposits. Modified from Giuliani (2011).

At the Lened locality in Canada's Northwest Territories, only about $5 \%$ of the beryl is transparent and bluish green (and can therefore be considered pale emerald), but it is the most recently studied Type IB occurrence. At Lened the emeralds are hosted by approximately 13 quartz veins that cut skarn in carbonate rocks and older strata. Beryllium and other incompatible elements $(\mathrm{W}, \mathrm{Sn}, \mathrm{Li}, \mathrm{B}$, and $\mathrm{F})$ in the emerald, vein minerals, and surrounding skarn were introduced during the terminal stages of crystallization of the proximal $\sim 100 \mathrm{Ma}$ Lened pluton (Lake et al., 2017). Decarbonation during pyroxene-garnet skarn formation in the host carbonate rocks probably caused local overpressuring and fracturing that allowed ingress of magmatic-derived fluids and formation of quartzcalcite-beryl-scheelite-tourmaline-pyrite veins. The chromophoric elements $(\mathrm{V}>\mathrm{Cr})$ were mobilized by metasomatism of metasedimentary rocks (black shale) that underlie the emerald occurrence (Lake et al., 2017).

The only Type IC deposit identified to date is in central Nigeria, where emerald occurs as a result of early metasomatic albitization (see Glossary) of an alkaline granite body of the Mesozoic Jos Ring Complex (Vapnik and Moroz, 2000) (figure 13). The emeralds occur with quartz, feldspar, and topaz in small pegmatitic pockets up to $8 \mathrm{~cm}$ in size at the granite-country rock contact, and in small miarolitic pockets in the roof of the granite, in a zone $<20 \mathrm{~m}$ from the contact with overlying rocks of the Nigerian Basement Complex (Schwarz et al., 1996). Chromium was likely incorporated from the basement schist or from younger volcanic rocks (Schwarz et al., 1996). Fluid inclusion data indicate emerald crystallization (of the 


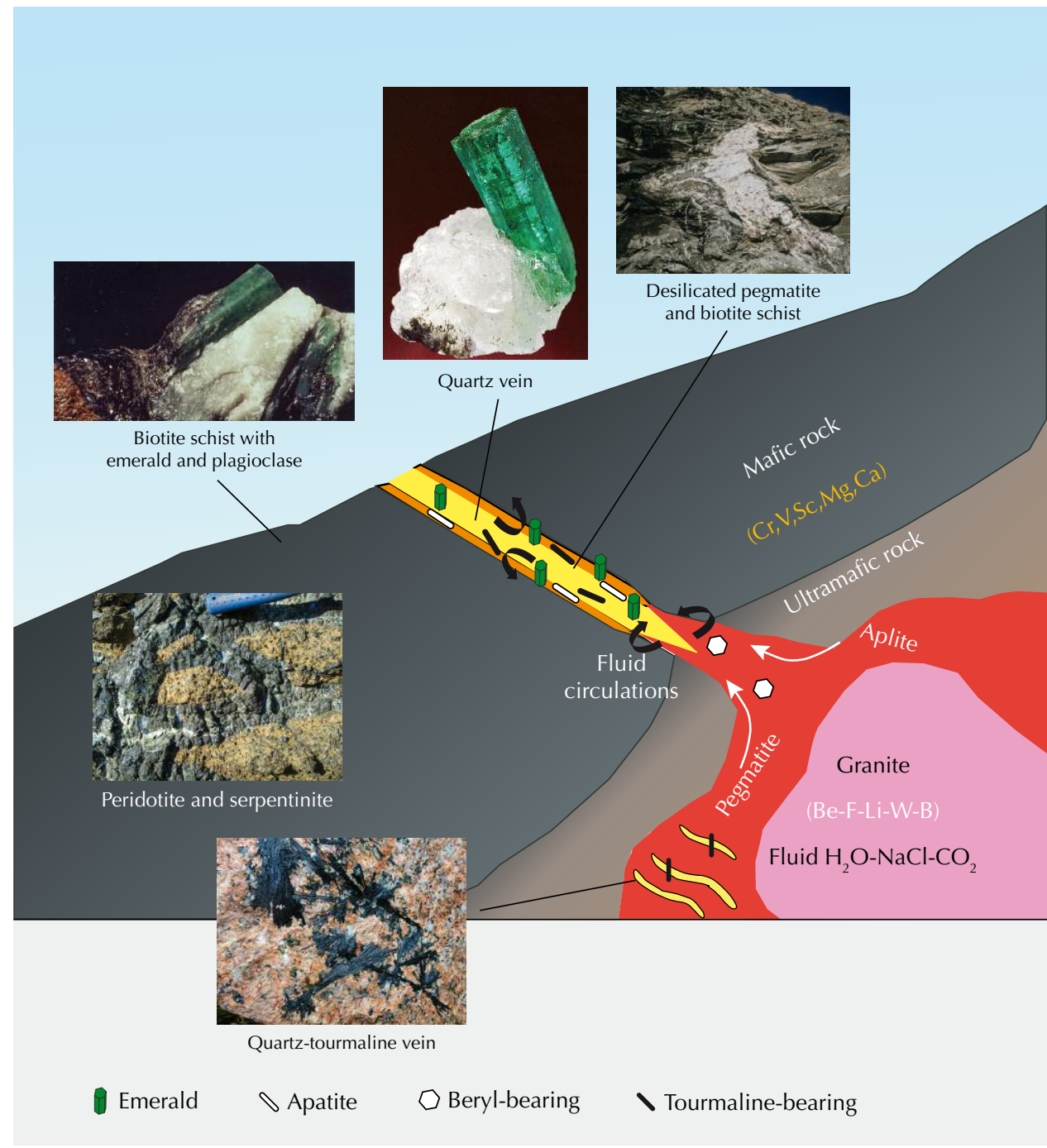

Figure 12. An idealized Type IA (tectonic-magmatic-related in maficultramafic rocks) deposit, in which a granite pluton with attendant pegmatite and aplite dikes and tourmaline-bearing and/or beryl-bearing quartz veins intrude mafic (metabasalt) and/or ultramafic (metaperidotite, serpentinite) rocks. Fluid circulation (indicated by the arrows) transforms the mafic rocks into a magnesium-rich biotite schist and the pegmatite into an albite-rich plagioclasite. Emerald and apatite can precipitate in the pegmatite, aplite, plagioclasite, and quartz veins, and in their adjacent phlogopite schist zones.

early and intermediate growth phases) at $400^{\circ}$ to $450^{\circ} \mathrm{C}$ and 0.2 to 0.3 kilobars (Vapnik and Moroz, 2000).

An example of a Type IIA deposit is Santa Terezinha in the Brazilian state of Goiás. This deposit, with emerald grades varying between 50 and 800 grams/ton, is associated with ductile shear zones cut- ting mafic and ultramafic rock formations (Giuliani et al., 1997a,b). The emeralds occur in phlogopitite and phlogopitized talc-carbonate schist (figure 14). The talc schist provided sites for thrusting that gave rise to the formation of sheath folds. Emeralds from Santa Terezinha are most commonly found in the

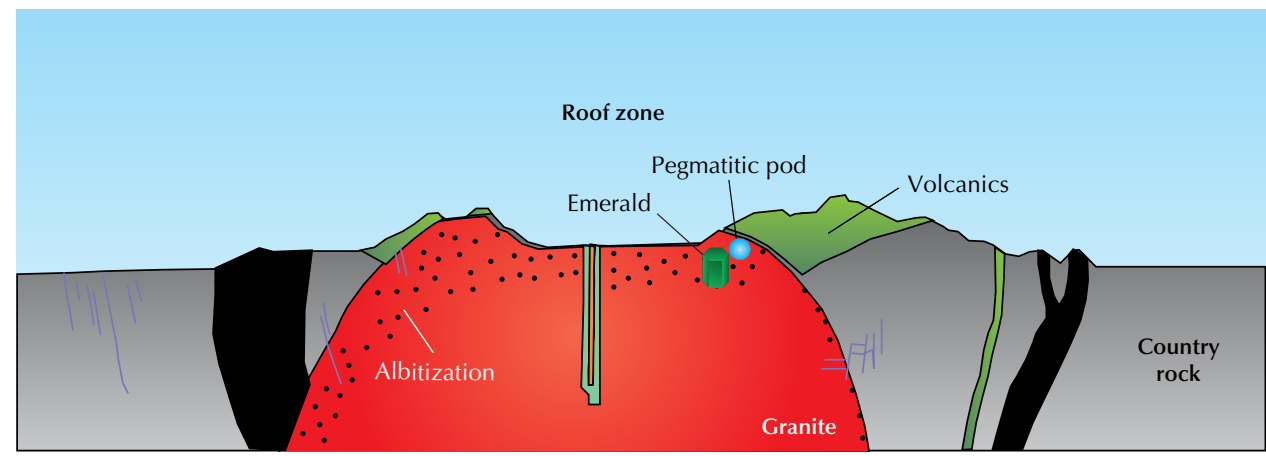

Figure 13. Geological schematic cross-section of ring complexes and their associated emerald mineralization in Nigeria. Modified from Kinnaird (1984). 

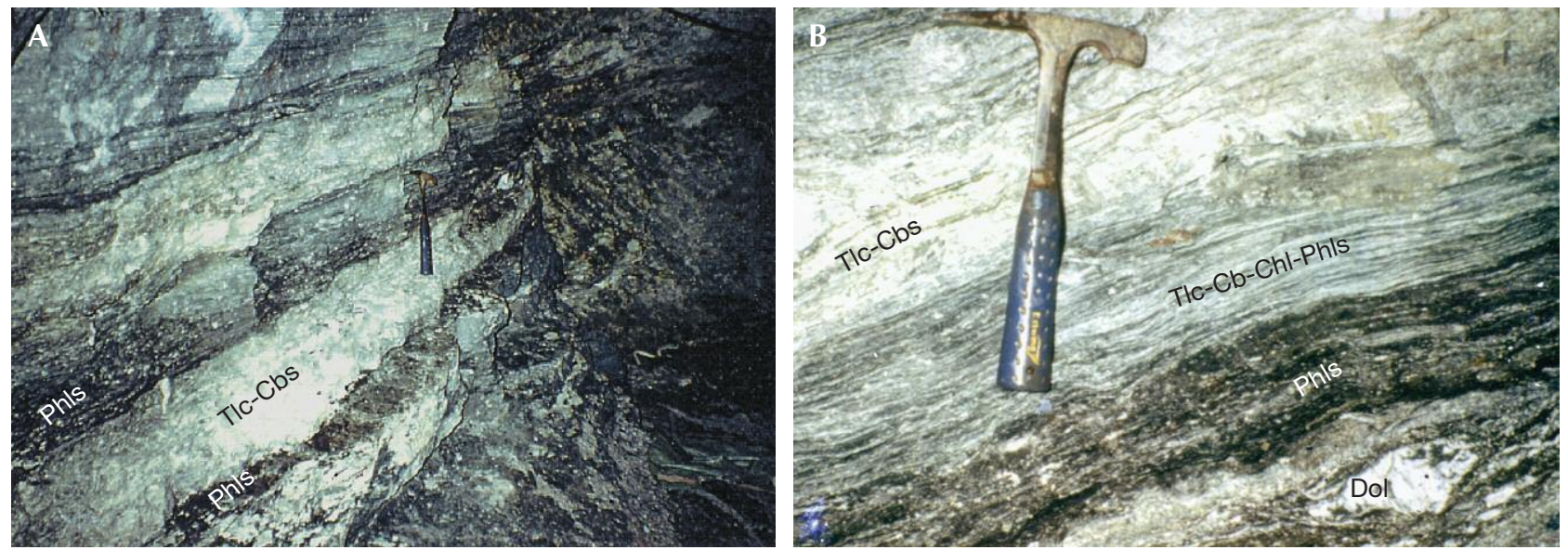

Figure 14. The Santa Terezinha de Goiás emerald deposit, Goiás State, Brazil. A: Phlogopite schist (Phls) and talccarbonate schists (Tlc-Cbs). B: With carbonate lenses (Dol). Phlogopitization affects the Tlc-Cbs and the talc-carbonate-chlorite-phlogopite schist (Tlc-Cb-Chl-Phls). Photos by G. Giuliani.

cores of the sheath folds and along the foliations. Isotopic data $\left(\delta^{18} \mathrm{O}\right.$ and $\delta \mathrm{D}$ for emerald and coeval phlogopite) are consistent with both magmatic and metamorphic fluids. However, the absence of granite and related pegmatites, and the low Be concentration in the volcano-sedimentary sequence $(<2$ ppmw), ex- clude a magmatic origin for Be. A metamorphic origin is therefore proposed for the Santa Terezinha parental fluids (Giuliani et al., 1997a,b).

The famous Colombian deposits (figure 15) are the best examples of Type IIB deposits. In Colombia, the emeralds occur in extensional carbonate-silicate-

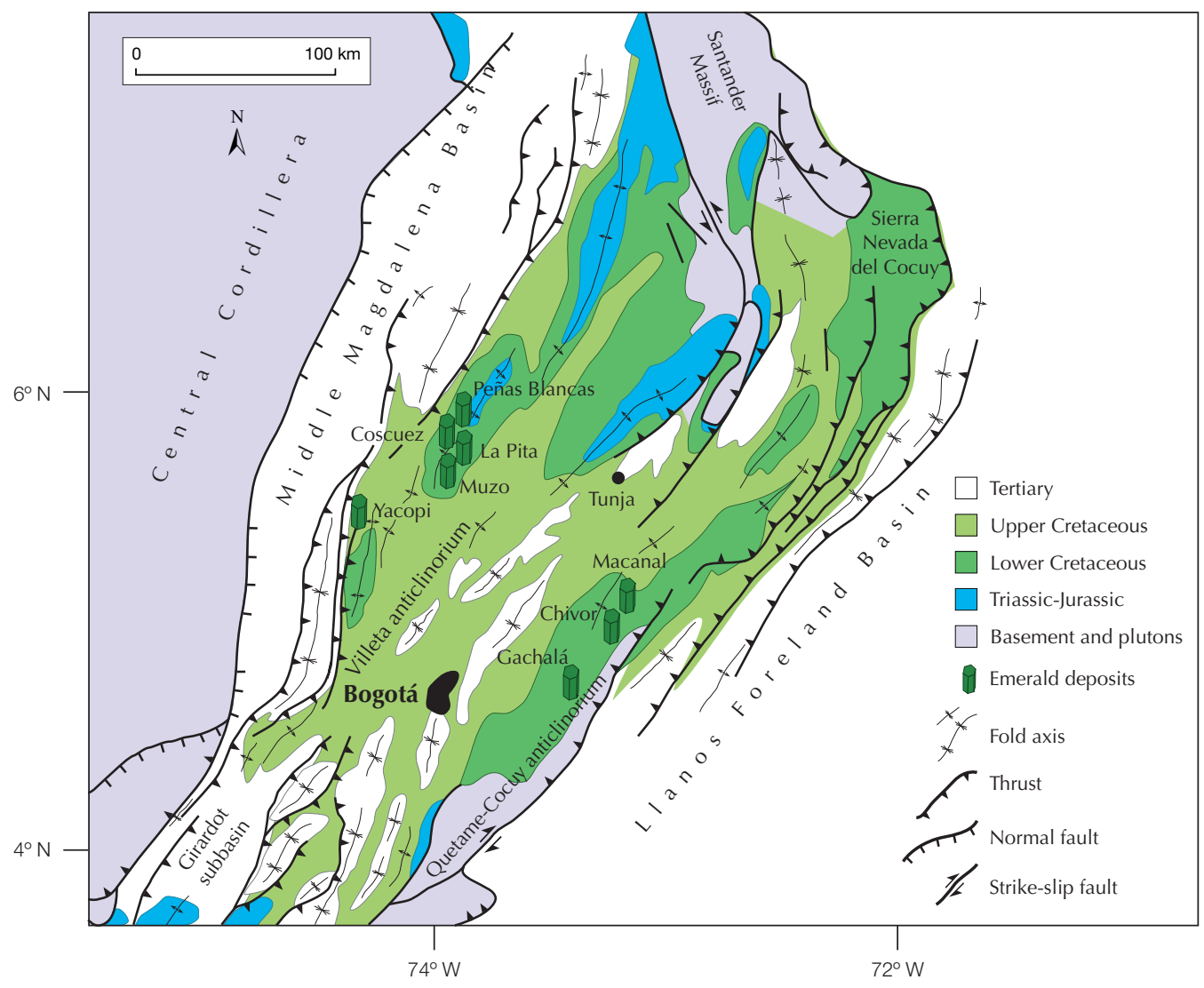

Figure 15. Generalized geological map of the Cordillera Oriental of Colombia showing the locations of the main emerald deposits. 

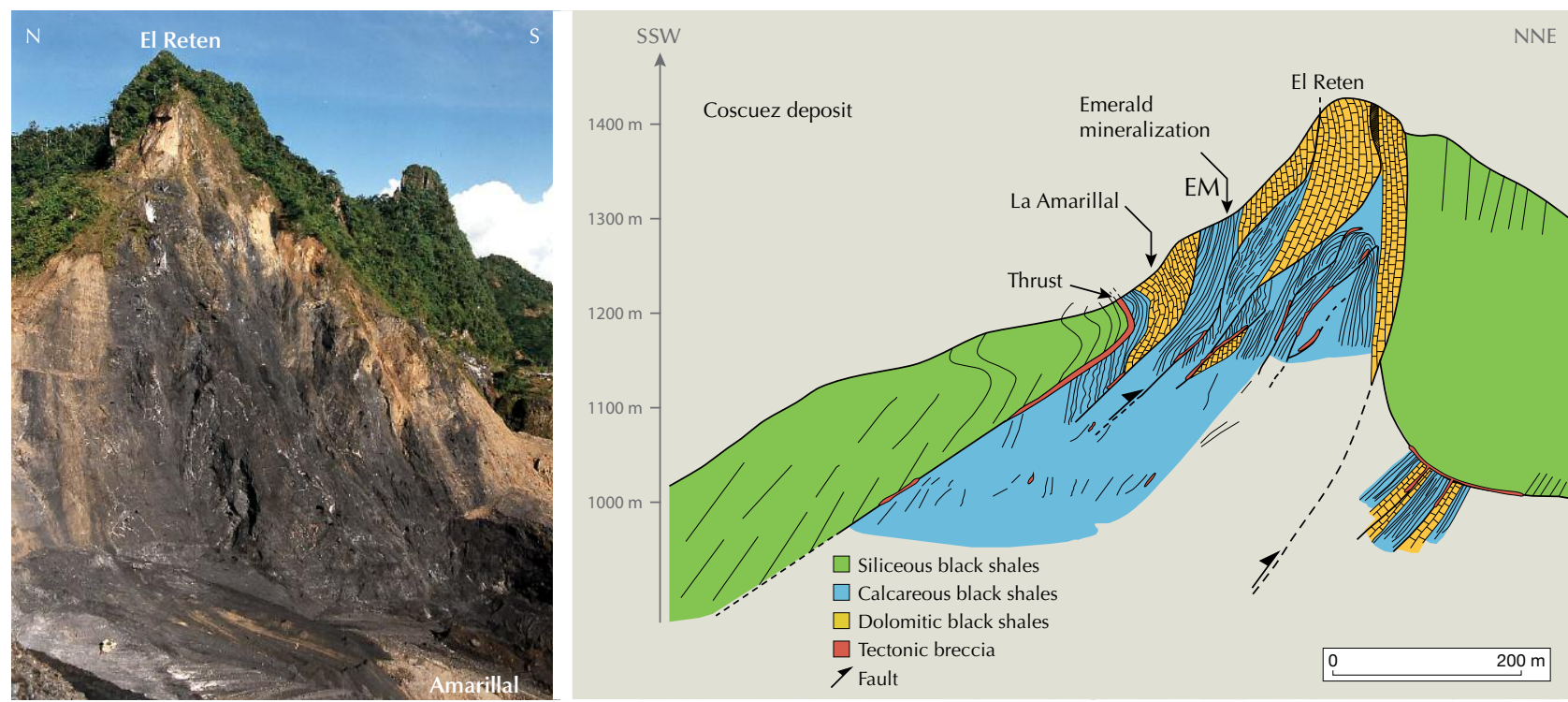

Figure 16. Left: View of the Coscuez deposit in 1996. Photo by G. Giuliani. Right: Geological cross-section of the Coscuez deposit.

pyrite veins, pockets, and breccia in an Early Cretaceous black shale-limestone succession (figure 16). The deposits are unusual because there is no evidence of magmatic activity. Instead, the emeralds formed as a result of hydrothermal growth associated with tectonic activity (Ottaway et al., 1994; Giuliani et al., 1995; Cheilletz and Giuliani, 1996; Branquet et al., 1999a,b). The parent fluids are thought to have formed at depth from meteoric and formational water interacting with salt beds and evaporitic sequences (Ottaway et al., 1994; Giuliani et al., 2000). These highly alkaline fluids (up to $40 \mathrm{wt}$. \% equivalent $\mathrm{NaCl}$ ) migrated upward through the sedimentary sequence along thrust planes and then interacted with the black shale. During Na and Ca metasomatism, major and trace elements (including $\mathrm{Be}, \mathrm{Cr}$, and V) were leached from the enclosing black shale; this first stage was accompanied by development of a vein system filled by fibrous calcite, bitumen, and pyrite. The second stage was characterized by extensional vein sets and hydraulic breccia development filled by muscovite, albite, calcite, dolomite, pyrite, and bitumen and by the precipitation in drusy cavities of fluorite, apatite, parisite-(Ce), dolomite, emerald, and quartz.

For many years it was assumed that Colombian deposits were unique, but in 2007 an unusual occurrence of green beryl (unfortunately not transparent enough for gem use) was discovered near Mountain River in Canada's Northwest Territories. This beryl is hosted by extensional quartz-carbonate veins cutting Neoproterozoic sandstone and siltstone. Re- search by Hewton et al. (2013) showed that the elements necessary to form beryl were liberated by inorganic thermochemical sulfate reduction via the circulation of warm basinal brines through siliciclastic, carbonate, and evaporitic rocks (figure 17). The Mountain River green beryl occurrence thus represents a variant of the Type IIB emerald deposit in the classification scheme of Giuliani et al. (2019) and suggests the potential for Colombian-type emerald mineralization in northwestern Canada.

Type IIC emerald deposits are further subdivided on the basis of the available examples. At the Panjshir Valley in Afghanistan (and Davdar in China) the host rock is a metamorphosed sedimentary rock and the formational fluids are metasomatic-hydrothermal in origin. At Hiddenite in northeastern North Carolina (United States), the host rock is a migmatite and the fluids are hydrothermal (Giuliani et al., 2019).

In Afghanistan the principal deposits lie within a $400 \mathrm{~km}^{2}$ area centered on the Panjshir Valley $130 \mathrm{~km}$ northeast of Kabul (Bowersox et al., 1991; Fijal et al., 2004). In the Khendj and adjacent valleys on the southeast side of the Panjshir Valley, the emerald occurrences are hosted by metamorphic schist that has been subjected to intense hydrothermal alteration. The altered zones are irregularly scattered along a fracture network and characterized by the development of albite, muscovite, biotite, tourmaline, and pyrite. Fluid inclusions in the emeralds are highly saline, which suggests that the southeast Panjshir Valley occurrences, like those in Colombia, are linked to hydrothermal fluids that derived their high 
salinity from leaching of evaporitic sequences (Giuliani et al., 1997a; Sabot et al., 2000; Vapnik and Moroz, 2001; Franz and Morteani, 2002; Giuliani et al., 2005). However, the metamorphic grade of the host rocks is higher than in the Colombian deposits. Sabot et al. (2000) suggested that the circulation of hydrothermal fluids resulted from tectonism that preceded uplift during the Himalayan orogeny.

At the Rist property northeast of Hiddenite, the emeralds occur in quartz veins and open cavities that occupy northeast-trending sub-vertical fractures in folded metamorphic rocks (Wise and Anderson, 2006). Emerald is associated with quartz, albite, beryl, calcite, dolomite, muscovite, rutile, spodumene, and siderite. The absence of pegmatites and the observed mineral assemblages suggest a hydrothermal origin. The source of $\mathrm{Be}$ and $\mathrm{Cr}$, and of the Li needed to crystallize emerald and spodumene, remains unknown.

Type IID deposits are metamorphosed Type IA (Habachtal in Austria; Djebel Sikait, Zabara, and Umm Kabu in Egypt; and probably Poona in Australia), mixed Type IA and IIA deposits in mafic-ultramafic rocks, and in deposits whose origin is unknown (e.g., Musakashi in Zambia) (Giuliani et al., 2019). These deposits have no economic interest, and the origin of the Be is unknown. In the Habachtal deposit, the metamorphic Habach Formation consists of a sequence of metapelite and metavolcanic rocks with interlayered serpentinite. The emeralds occur within metasomatic biotite schist, called "blackwall" zones, developed between these rocks as a result of regional metamorphism involving intense deformation. Geochemical analyses show that the entire "blackwall" zone is enriched in Be, which Grundmann and Morteani (1989) suggested originated with submarine volcanic exhalations. Mass balance calculations suggested that the transformation of serpentinite and Be-rich country rocks released excess Be to form emerald in the blackwall zone (figure 18). The source of the $\mathrm{Cr}$ is the metasomatized ultrabasic rocks. Grundmann and Morteani (1989) argued for a regional metamorphic origin for the emeralds. Zwaan (2006) was critical of this interpretation and warned that in cases where pegmatitic sources of Be are not apparent, one must proceed with caution since fluids can travel far from pegmatites, especially along intensely sheared rocks. Zwaan (2006) also pointed out that pegmatites do occur in the Habach Formation and that the Habachtal emeralds contain up to 760 ppmw Cs /Calligaro et al., 2000), which suggests a pegmatitic source, and sulfide deposits related to submarine volcanic exhalation are not generally enriched in Be.

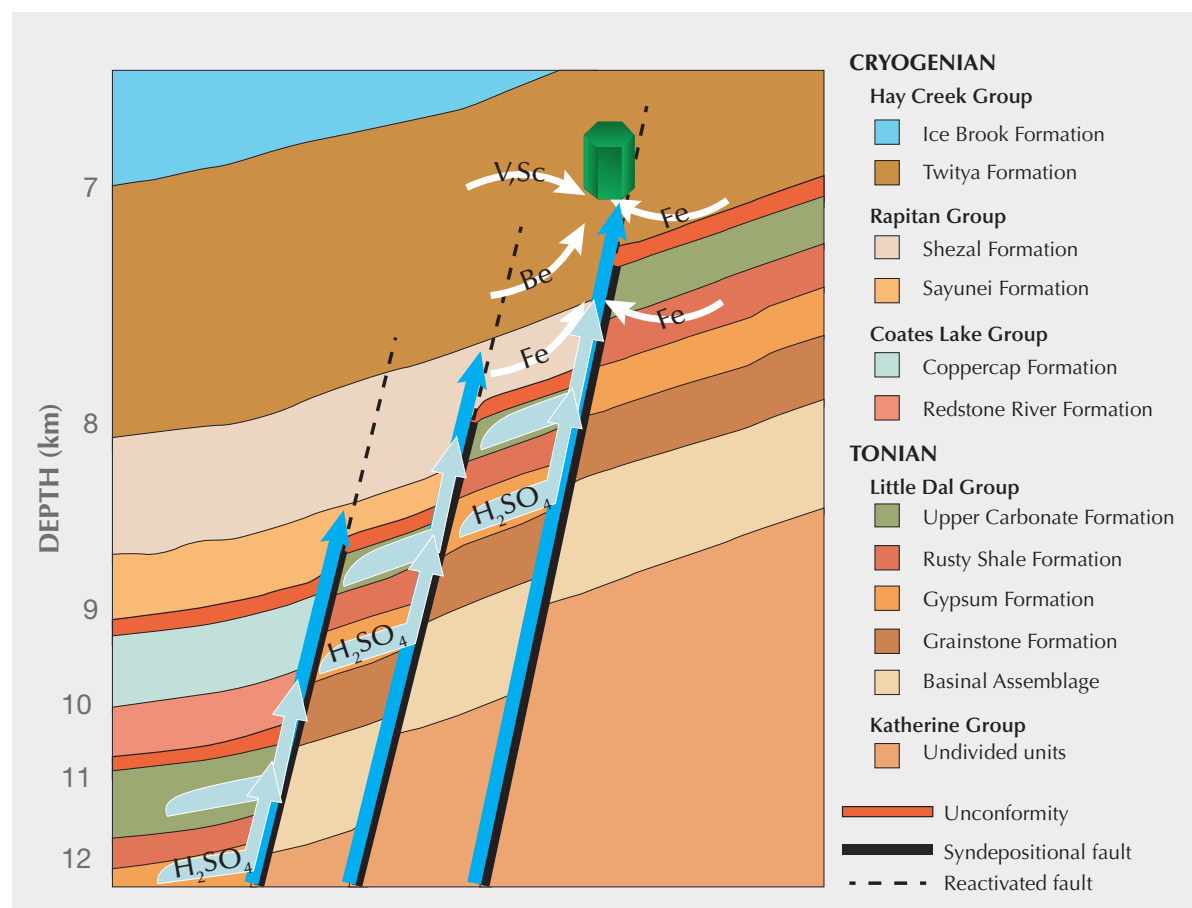

Figure 17. Genesis of the Mountain River occurrence in Canada. The blue arrows indicate fluid movement, and the light blue arrows indicate derivation of salts and sulfate. Modified from Hewton et al. (2013). 


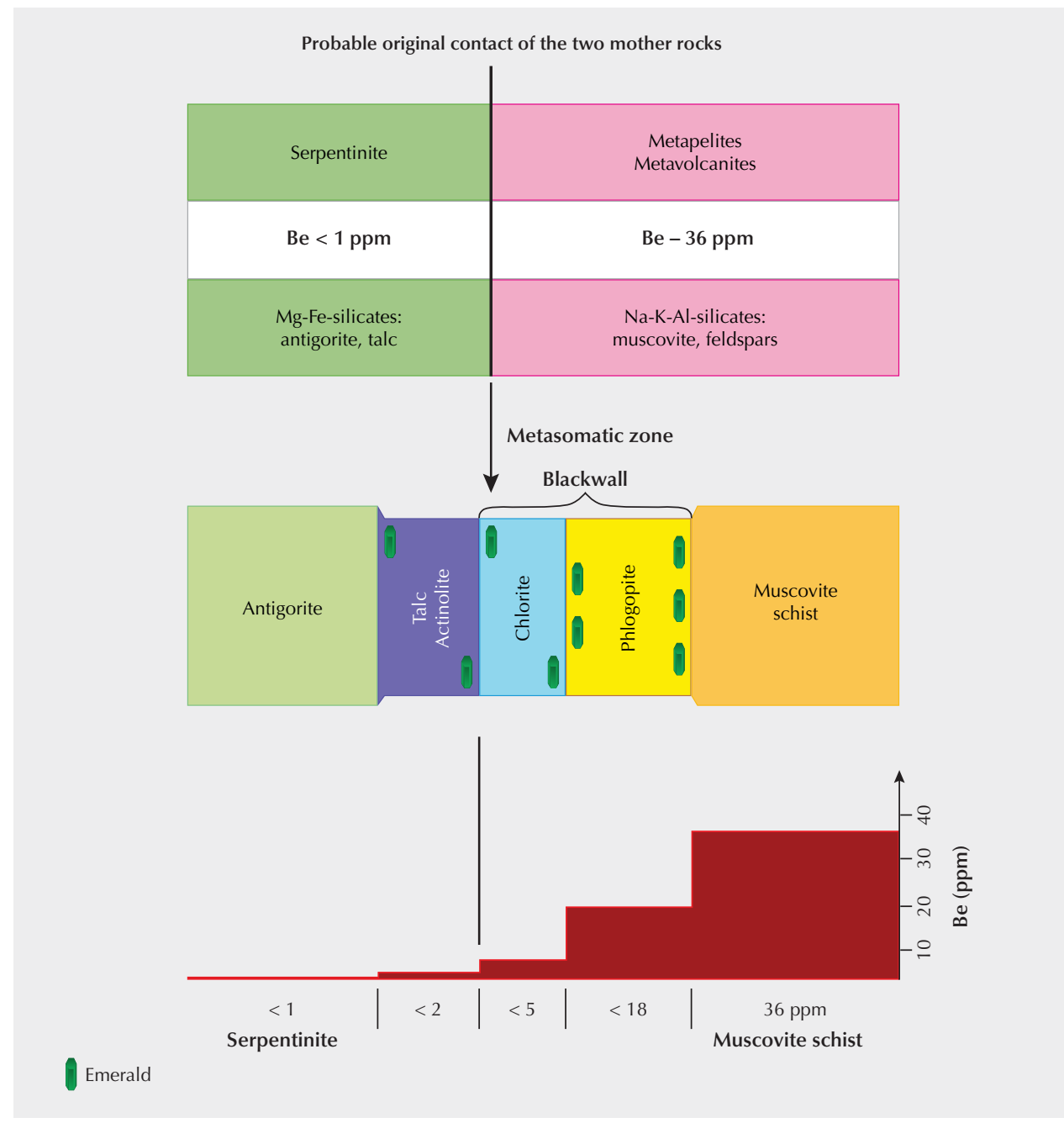

Figure 18. Model for formation of the Habachtal emerald deposit in Austria. Top: Initial stage showing the different lithologies with their respective Be contents. Middle: Final stage after regional metamorphism showing the final metasomatic rock assemblages. Bottom: Be liberated from the muscovite schists is incorporated into the emerald crystals. Modified from Grundmann and Morteani (1989).

\section{SUMMARY}

This paper is a brief review of the state of our knowledge of the geology and genesis of gem corundum and emerald deposits. The genetic models provide guidelines for prospecting and conceptual understanding, help to forecast the location of undiscovered gem deposits, and give geologic and geographic clues on the origins of ruby, sapphires, and emerald. Over the last two decades, knowledge of the formation of these deposits has improved significantly. For example, we now know that ruby in marbles in Southeast Asia and Central Asia result from the metamorphism of Al-bearing limestone and melting of evaporites. Today, most gem corundum production is from placers related to alkali basalt, plumasite, skarn, marble, and amphibolites. Sri Lanka and Madagascar remain important sources of high-quality metamorphic blue sapphire, Mozambique and northeastern Madagascar for top-quality ruby, and Southeast Asia and Australia for BGY sapphires. Most emerald production is from hard-rock mines in Colombia, Zambia, and Brazil.

\section{ABOUT THE AUTHORS}

Dr. Giuliani is a senior researcher at Université Paul Sabatier, GET/IRD and Université de Lorraine, CRPG/CNRS, Vandœuvre, France. Dr. Groat is a professor in the Department of Earth, Ocean and Atmospheric Sciences at the University of British Columbia in Vancouver.

\section{ACKNOWLEDGMENTS}

The authors would like to thank the editorial board of G\&G for the invitation to contribute on the state of our knowledge on the geology and genesis of corundum and emerald deposits. We also thank two anonymous reviewers and Dr. Lin Sutherland for their constructive comments as well as the editorial support and improvement done by G\&G. 
Albitization: Partial or complete replacement of pre-existing plagioclase feldspar or alkali feldspar by albite in an igneous rock; commonly due to the residual water-rich vapor released during the final stages of crystallization of a granite body. The circulation of highly Na-rich saline hydrothermal fluids in fractures can also produce the albitization of rocks of different nature.

Alkali basalt: A type of basalt found in oceanic and continental areas associated with volcanic activity, such as oceanic islands, continental rifts, and volcanic fields; characterized by relatively high alkali $\left(\mathrm{Na}_{2} \mathrm{O}\right.$ and $\left.\mathrm{K}_{2} \mathrm{O}\right)$ content relative to other basalts; may originate at greater depths in the mantle (150-200 km) than most basalts (50-100 km).

Basaltic: Referring to a dark-colored, fine-grained igneous rock, composed mainly of plagioclase feldspar and pyroxene, formed by the solidification of magma near the earth's surface.

Breccia: A coarse-grained rock of sedimentary or igneous origin that is composed of angular rock fragments held together by a mineral cement or fine-grained matrix. Brecciation is the process of forming a breccia or the magma that crystallizes such a rock.

Cambrian: The first geological period of the Paleozoic Era, which spans time in the earth's history from 541 to 485.4 million years ago.

Carbonatitic: Refers to a magma composed mostly of molten carbonate minerals.

Clinopyroxenite: A rock composed dominantly of clinopyroxene. Typically refers to ultramafic igneous rocks that are often genetically related to other mafic/ultramafic rocks such as gabbros and peridotites.

Cretaceous: A geological period of the Mesozoic Era spanning in time from 145 to 66 million years ago.

Eclogite: A rock composed dominantly of pyrope-almandine garnet and $\mathrm{Na}$-rich clinopyroxene. Eclogites are generally noted for their lack of plagioclase feldspar and typically form through metamorphism of mafic rocks at very high pressures, usually in the earth's mantle or in very thick sections of the crust.

Gneiss: Metamorphic rock identified by its banded appearance and texture; bands contain interlocking granular minerals or elongate minerals with evidence of preferred orientation; gneiss forms by regional metamorphism at convergent plate boundaries.

Granitoid: Coarse-grained plutonic igneous rocks composed mostly of feldspars and quartz with minor accessory minerals such as micas. Granitoid is a general term that includes granites and other mineralogical and compositionally similar plutonic rocks.

Granulite: Rocks that have experienced high-grade metamorphism at high temperature and medium to high pressure. Temperatures are generally high enough to initiate partial melting in granulites.
Komatiite: Ultramafic volcanic rocks with very high magnesium contents. Komatiites are very rare and generally confined to the Archean and Hadean Eons.

Lamprophyre: A group of dark-colored intrusive igneous rocks characterized by a high percentage of mafic minerals (such as biotite mica, hornblende, and pyroxene) as larger crystals, set in a fine-grained groundmass composed of the same minerals plus feldspars or feldspathoids.

Laterite: A soil rich in iron and aluminum, considered to have formed in hot and wet tropical areas.

Limestone: A sedimentary rock composed dominantly of calcium carbonate $\left(\mathrm{CaCO}_{3}\right)$. Limestones generally form through the gradual accumulation of the skeletal remains of marine organisms onto the seafloor over time.

Mafic: A dark-colored igneous rock chiefly composed of iron- and magnesium-rich minerals.

Mafic-ultramafic: See mafic and ultramafic.

Magmatic deposit: A deposit related to or derived from magma.

Mantle plume: An upwelling of hot rock rising up through the earth's mantle that is one of the likely mechanisms of convection and heat transfer in the earth. Mantle plumes are accompanied by extensive volcanism resulting from decompression of hot rocks originating deep within the mantle.

Megacryst: A crystal in an igneous or metamorphic rock that is significantly larger than those in the surrounding groundmass or matrix.

Mesozoic: The geological era containing the Triassic, Jurassic, and Cretaceous periods. The Mesozoic Era lasted from 252 to 66 million years ago.

Metabasite: The metamorphosed version of low-silica mafic, originally igneous rocks.

Metamorphic: Related to a process that causes mineralogical, chemical, or structural changes in solid rocks by exposing them to new pressure and temperature conditions by burial within the crust or mantle.

Metapelite: A metamorphosed fine-grained sedimentary rock (e.g., mudstone or siltstone).

Metasedimentary: A metamorphosed version of an originally sedimentary rock (e.g., marble or slate).

Metasomatic: Formed by metasomatism, a geologic process that produces new minerals in an existing rock by replacement.

Metavolcanic: A metamorphosed version of a volcanic rock.

Miarolitic: Crystal-lined irregular cavities or vugs most commonly found in granitic pegmatites, and also in a variety of other igneous rocks.

Neoproterozoic: A geological era from 1,000 to 541 million years ago belonging to the Proterozoic Eon.

Orogeny: The processes by which geologic structures in 
mountainous regions are formed. These processes include thrusting, folding, faulting, and (at depth) metamorphism and igneous intrusions.

Ouachitite: Pronounced "wash-e-tite," this is a specific type of lamprophyre, predominantly composed of phenocrysts (large crystals) of mica and clinopyroxene set within a groundmass of fine-grained mica and clinopyroxene with minor analcime, calcite, corundum, and other trace accessory minerals.

Pegmatite: Intrusive igneous rock with a texture of exceptionally large mineral grains (by convention, the largest are more than about $3 \mathrm{~cm}$ long); most pegmatites are composed of quartz, feldspar, and mica (similar composition as granite); sometimes contain minerals that are rarely found in other types of rocks, including gems.

Phlogopite: A brown micaceous mineral that occurs chiefly in metamorphosed limestone and magnesium-rich igneous rocks. It consists of hydrous silicate of potassium and magnesium and aluminum.

Phonolite: Uncommon, fine-grained volcanic igneous rock consisting of alkaline feldspars (sanidine, anorthoclase or orthoclase) and nepheline.

Placer: A surface deposit consisting of valuable minerals that have been weathered out and then mechanically concentrated (normally by flowing water) in alluvial sediments.

Plumasite: Metasomatic rock, typically coarse-grained and found especially in dikes, consisting chiefly of corundum grains in a plagioclase feldspar matrix. It results from the circulation of hydrothermal fluids into a generally granitoid dike.

Plutonic: Igneous rock formed by slow cooling of magma that is intruded into the earth's crust.

Shear zone: The result of large-volume rock deformation due to intense regional stress, typically in continental collisional plates, as in the Himalayas today, at depths down to few kilometers; may occur at the edges of tectonic blocks, forming discontinuities that mark a distinct structure.

Skarn: Metasomatic rocks composed of calcium-magnesium-aluminum silicate minerals resulting from fluid-rock interaction of hydrothermal fluids with $\mathrm{Ca}-\mathrm{Mg}$-rich rocks. Generally, they form locally when a granitic pluton intrudes limestone or Ca-Mg-rich rocks.

Syenite: A coarse-grained intrusive igneous rock with a general composition similar to that of granite, but with a lower quartz content (typically $<5 \%$ ).

Syngenetic: Refers to an inclusion that formed at the same time as the host gem.

Ultramafic: An igneous rock composed mainly of mafic (iron and magnesium-rich) minerals.

Xenocryst: A large crystal in an igneous rock that is foreign to the rock in which it occurs.

Xenolith: An inclusion of a foreign rock in an igneous rock.

\section{REFERENCES}

Abduriyim A., Sutherland F.L., Coldham T. (2012) Past, present and future of Australian gem corundum. Australian Gemmologist, Vol. 24, No. 10, pp. 234-242.

Atkinson D., Kothavala R.Z. (1983) Kashmir sapphire. Ge)G, Vol. 19, No. 2, pp. 64-76, http://dx.doi.org/10.5741/GEMS.19.2.64

Baldwin L.C., Tomaschek F., Ballhaus C., Gerdes A., Fonseca R.O.C, Wirth R., Geisler T., Nagel T. (2017) Petrogenesis of alkaline basalthosted sapphire megacrysts. Petrological and geochemical investigations of in situ sapphire occurrences from the Siebengebirge Volcanic Field, Germany. Contributions to Mineralogy and Petrology, Vol. 172, No. 6, http://dx.doi.org/10.1007/s00410-017-1362-0

Behling S., Wilson W.E. (2010) The Kagem emerald mine: Kafubu area, Zambia. Mineralogical Record, Vol. 41, No. 1, pp. 59-68.

Berg R.B. (2007) Sapphires in the Butte-Deer Lodge area, Montana. Montana Bureau of Mines and Geology Bulletin, No. 134, 62 pp.

Berg R.B., Palke A.C. (2016) Sapphires from an eocene sill near Helena, Montana. Geological Society of America Abstracts with Programs, Vol. 48, No. 7, http://dx.doi.org/10.1130/abs/2016AM278371

Bowersox G.W., Snee L.W., Foord E.F., Seal R.R. II. (1991) Emeralds of the Panjshir Valley, Afghanistan. $G \uplus G$, Vol. 27, No. 1, pp. 26-39, http://dx.doi.org/10.5741/GEMS.27.1.26

Branquet Y., Laumonier B., Cheilletz A., Giuliani G. (1999a) Emeralds in the Eastern Cordillera of Colombia: Two tectonic settings for one mineralization. Geology, Vol. 27, No. 7, pp. 597-600, http://dx.doi.org/10.1130/0091-7613(1999)027\%3C0597:EIT$\mathrm{ECO} \% 3 \mathrm{E} 2.3 . \mathrm{CO} ; 2$

Branquet Y., Cheilletz A., Giuliani G., Laumonier Blanco O. (1999b) Fluidized hydrothermal breccia in dilatant faults during thrusting: The Colombian emerald deposits. In K.J.W. McCaffrey, L. Lonergan, and J.J. Wilkinson, Eds., Fractures, Fluid Flow and Mineralization, Geological Society of London, Special Publications, Vol. 155, No. 1, pp. 183-195, http://dx.doi.org/ 10.1144/GSL.SP.1999.155.01.14

Branstrator B. (2017) Gemfields sells 6,100-ct rough emerald at Oct. auction. National Jeweler, October 11, https://www.nationaljeweler.com/diamonds-gems/supply/5911-gemfieldssells-6-100-ct-rough-emerald-at-oct-auction

Brownlow A.H., Komorowski J.-C. (1988) Geology and origin of the Yogo sapphire deposit, Montana. Economic Geology, Vol. 83 No. 4, pp. 875-880, http://dx.doi.org/10.2113/gsecongeo.83.4.875

Calligaro T., Dran J.-C., Poirot J.P., Querré G., Salomon J., Zwaan J.C. (2000) PIXE/PIGE characterisation of emeralds using an external micro-beam. Nuclear Instruments and Methods in Physics Research Section B, Vol. 161-163, pp. 769-774, http://dx.doi.org/ 10.1016/S0168-583X(99)00974-X

Cheilletz A., Giuliani G. (1996) The genesis of Colombian emeralds: A restatement. Mineralium Deposita, Vol. 31, No. 5, pp. 359-364, http://dx.doi.org/10.1007/BF00189183

Cheilletz A., Sabot B., Marchand P., De Donato P., Taylor B., Archibald D., Barres O., Andrianjaffy J. (2001) Emerald deposits in Madagascar: Two different types for one mineralising event. European Union of Geosciences Conference Abstracts, Vol. 6, p. 547.

Dharmaratne P.G.R., Premasiri H.M.R., Dillimuni D. (2012) Sapphires from Thammannawa, Kataragama area, Sri Lanka. $G \uplus G$, Vol. 48, No. 2, pp. 98-107, http://dx.doi.org/10.5741/ 
GEMS.48.2.98

Dill H.G. (2018) Gems and placers-A genetic relationship par excellence. Minerals, Vol. 8, No. 10, pp. 470-513, http://dx.doi.org/ $10.3390 / \mathrm{min} 8100470$

Fagan A.J. (2015) True North Gems Greenland mining - The final lap. InColor, No. 29, pp. 36-49.

Fagan A.J. (2018) The ruby and pink sapphire deposits of SW Greenland: Geological setting, genesis, and exploration techniques. $\mathrm{PhD}$ Thesis, University of British Columbia, Vancouver, $747 \mathrm{pp}$.

Fijal J., Heflik W., Natkaniec-Nowak L., Szczepaniak A. (2004) Emeralds from the Panjshir Valley (Afghanistan). Gemmologie: Zeitschrift der Deutschen Gemmologischen Gesellschaft, Vol. 53 , No. 4, pp. 127-142.

Franz G., Morteani G. (2002) Be-minerals: Synthesis, stability, and occurrence in metamorphic rocks. Reviews in Mineralogy and Geochemistry, Vol. 50, No. 1, pp. 551-589, http://dx.doi.org/ 10.2138/rmg.2002.50.13

Garnier V., Ohnenstetter D., Giuliani G., Schwarz D. (2004) Saphirs et rubis: Classification des gisements de corindon. Le Règne Minéral, Vol. 55, pp. 4-47.

Garnier V., Giuliani G., Ohnenstetter D., Fallick A.E., Dubessy J., Banks D., Hoàng Q.V., Lhomme T., Maluski H., Pêcher A., Bakhsh K.A., Pham V.L., Phan T.T., Schwarz D. (2008) Marblehosted ruby deposits from central and Southeast Asia: Towards a new genetic model. Ore Geology Reviews, Vol. 34, No. 1-2, pp. 169-191, http://dx.doi.org/10.1016/j.oregeorev.2008.03.003

Gemfields (2018) Gemfields introduces 'Inkalamu', the 5,655 carat Lion Emerald. October 29, https://gemfields.com/gemfields-introduces-inkalamu-the-5655-carat-lion-emerald/

Giuliani G. (2011) La spirale du temps de l'émeraude. Le Règne Minéral, Vol. 98, pp. 31-44.

Giuliani G., Cheilletz A., Arboleda C., Carrillo V., Rueda F., Baker J.H. (1995) An evaporitic origin of the parent brines of Colombian emeralds: Fluid inclusion and sulphur isotope evidence. European Journal of Mineralogy, Vol. 7, No. 1, pp. 151-165, http://dx.doi.org/10.1127/ejm/7/1/0151

Giuliani G., France-Lanord C., Zimmermann J.L., Cheilletz A., Arboleda C., Charoy B., Coget P., Fontan F., Giard D. (1997a) Fluid composition, $\delta \mathrm{D}$ of channel $\mathrm{H}_{2} \mathrm{O}$, and $\delta^{18} \mathrm{O}$ of lattice oxygen in beryls: Genetic implications for Brazilian, Colombian, and Afghanistani emerald deposits. International Geology Review, Vol. 39, No. 5, pp. 400-424, http://dx.doi.org/10.1080/ 00206819709465280

Giuliani G., Cheilletz A., Zimmermann J.L., Ribeiro-Althoff A.M., France-Lanord C., Féraud G. (1997b) Les gisements d'émeraude du Brésil: Genèse et typologie. Chronique de la Recherche Minière, Vol. 526, pp. 17-61.

Giuliani G., Christian F.L., Cheilletz A., Coget P., Branquet Y., Laumonier B. (2000) Sulfate reduction by organic matter in Colombian emerald deposits: Chemical and stable isotope (C, O, H) evidence. Economic Geology, Vol. 95, No. 5, pp. 11291153, http://dx.doi.org/10.2113/gsecongeo.95.5.1129

Giuliani G., Fallick A.E., Garnier V., France-Lanord C., Ohnenstetter D., Schwarz D. (2005) Oxygen isotope composition as a tracer for the origins of rubies and sapphires. Geology, Vol. 33, No. 4, pp. 249-252, http://dx.doi.org/10.1130/G21261.1

Giuliani G., Ohnenstetter D., Garnier V, Fallick A.E., Rakotondrazafy A.F.M., Schwarz D. (2007a) The geology and genesis of gem corundum deposits. In L.A. Groat, Ed., Geology of Gem Deposits, 1st ed., Mineralogical Association of Canada, Short Course Series 37, Yellowknife, Canada, pp. 23-78.

Giuliani G., Fallick A.E., Rakotondrazafy A.F.M., Ohnenstetter D., Andriamamonjy A., Rakotosamizanany S., Ralantoarison T., Razanatseheno M.M., Dunaigre C., Schwarz D. (2007b) Oxygen isotope systematics of gem corundum deposits in Madagascar: Relevance for their geological origin. Mineralium Deposita, Vol. 42, No. 3, pp. 251-270, http://dx.doi.org/10.1007/s00126-006-0105-3

Giuliani G., Ohnenstetter D., Fallick A.E., Groat L., Feneyrol J. (2012) Geographic origin of gems linked to their geological his- tory. InColor, No. 19, pp. 16-27

Giuliani G., Ohnenstetter D., Fallick A.E., Groat L.A., Fagan A.J. (2014) The geology and genesis of gem corundum deposits. In L.A. Groat, Ed., Geology of Gem Deposits, 2nd ed., Mineralogical Association of Canada, Short Course Series 44, pp. 29-112. Giuliani G., Dubessy J., Banks D., Lhomme T., Ohnenstetter D. (2015) Fluid inclusions in ruby from Asian marble deposits: Genetic implications. European Journal of Mineralogy, Vol. 27, No. 3, pp. 393-404, http://dx.doi.org/10.1127/ejm/2015/0027-2442

Giuliani G., Dubessy J., Ohnenstetter D., Banks D., Branquet Y., Feneyrol J., Fallick A.E., Martelat J.-E. (2018) The role of evaporites in the formation of gems during metamorphism of carbonate platforms: A review. Mineralium Deposita, Vol. 53, No. 1, pp. 1-20, http://dx.doi.org/10.1007/s00126-017-0738-4

Giuliani G., Groat L.A., Marshall D., Fallick A.E., Branquet Y. (2019) Emerald deposits: A review and enhanced classification. Minerals, Vol. 9, No. 2, pp. 105-168, http://dx.doi.org/10.3390/ $\min 9020105$

Graham I.T., Sutherland F.L., Webb G.B., Fanning C.M. (2004) Polygenetic corundums from New South Wales gemfields. In A.I Khanchuk, G.A. Gonevchuk, A.N. Mitrokhin, I.F. Simanenko, N.J. Cook, R. Seltmann, Eds., Metallogeny of the Pacific Northwest: Tectonics, Magmatism and Metallogeny of Active Continental Margins. Dalnauka, Vladivostok, Russia, pp. 336-339.

Graham I., Sutherland L., Zaw K., Nechaev V., Khanchuk A. (2008) Advances in our understanding of the gem corundum deposits of the West Pacific continental margins intraplate basaltic fields. Ore Geology Reviews, Vol. 34, No 1-2, pp. 200-215, http://dx.doi.org/10.1016/j.oregeorev.2008.04.006

Grundmann G., Giuliani G. (2002) Emeralds of the world. extraLapis English, No. 2, pp. 24-35.

Grundmann G., Morteani G. (1989) Emerald mineralization during regional metamorphism; the Habachtal (Austria) and Leydsdorp (Transvaal, South Africa) deposits. Economic Geology, Vol. 84, No. 7, pp. 1835-1849, http://dx.doi.org/10.2113/gsecongeo.84.7.1835

Grundmann G., Morteani G. (1993) Emerald formation during regional metamorphism: The Zabara, Sikeit and Umm Kabo deposits (Eastern Desert, Egypt). In U. Thorweihe and $\mathrm{H}$. Schandelmeir, Eds., Geoscientific Research in Northeast Africa, pp. 495-498, http://dx.doi.org/10.1201/9780203753392-90

Guo J., O'Reilly S.Y., Griffin W.L. (1996) Corundum from basaltic terrains: A mineral inclusion approach to the enigma. Contributions to Mineralogy and Petrology, Vol. 122, No. 4, pp. 368386, http://dx.doi.org/10.1007/s004100050134

Hewton M.L., Marshall D.D., Ootes L., Loughrey L.E., Creaser R.A. (2013) Colombian-style emerald mineralization in the northern Canadian Cordillera: Integration into a regional Paleozoic fluid flow regime. Canadian Journal of Earth Sciences, Vol. 50, No. 8, pp. 857-871, http://dx.doi.org/10.1139/cjes-2012-0128

Hughes R.W. (1997) Ruby e) Sapphire. RWH Publishing, Boulder, Colorado, $512 \mathrm{pp}$.

In the News: Gemfields' October emerald auction: US\$21.5 million in sales (2018) InColor, No. 37, p. 22.

John T., Schenk V., Mezger K., Tembo F. (2004) Timing and PT evolution of whiteschist metamorphism in the Lufilian Arc-Zambezi Belt orogen (Zambia): Implications for the assembly of Gondwana. Journal of Geology, Vol. 112, No. 1, pp. 71-90, http://dx.doi.org/10.1086/379693

Jöns N., Schenk V. (2008) Relics of the Mozambique Ocean in the central East African orogen: Evidence from the Vohibory Block of southern Madagascar. Journal of Metamorphic Geology, Vol. 26, No. 1, pp. 17-28, http://dx.doi.org/10.1111/j.1525-1314. 2007.00745.x

Kane R.E., Kammerling R.C. (1992) Status of ruby and sapphire mining in the Mogok stone tract. Ge G, Vol. 28, No. 3, pp. 152174, http://dx.doi.org/10.5741/GEMS.28.3.152

Kievlenko E.Y. (2003) Geology of Gems. Ocean Publications Ltd, Littleton, Colorado, pp. 432. 
Kinnaird J.A. (1984) Contrasting styles of Sn-Nb-Ta-Zn mineralization in Nigeria. Journal of African Earth Sciences, Vol. 2, No. 2, pp. 81-90, http://dx.doi.org/10.1016/S0731-7247/84/80001-4

Krebs M.Y., Pearson D.G., Fagan A.J., Bussweiler Y., Sarkar C. (2019) The application of trace elements and $\mathrm{Sr}-\mathrm{Pb}$ isotopes to dating and tracing ruby formation: The Aappaluttoq deposit, SW Greenland. Chemical Geology, Vol. 523, pp. 42-58, http://dx.doi.org/10.1016/i.chemgeo.2019.05.035

Kröner A. (1984) Late Precambrian plate tectonics and orogeny: A need to redefine the term Pan-African. In J. Klerkx and J. Michot, Eds., African Geology. Musée Royal de l'Afrique Centrale, Tervuren, Belgium, pp. 23-28.

Lake D.J., Groat L.A., Falck H., Cempirek J., Kontak D., Marshall D., Giuliani G., Fayek M. (2017) Genesis of emerald-bearing quartz veins associated with the Lened W-skarn mineralization, Northwest Territories, Canada. Canadian Mineralogist, Vol. 55, No. 4, pp. 561-593, http://dx.doi.org/10.3749/canmin.1700025

Le Goff E., Deschamps Y., Guerrot C. (2010) Tectonic implications of new single zircon $\mathrm{Pb}-\mathrm{Pb}$ evaporation data in the Lossogonoi and Longido ruby-districts, Mozambican metamorphic Belt of north-eastern Tanzania. Comptes Rendus Geoscience, Vol. 342, No. 1, pp. 36-45, http://dx.doi.org/10.1016/j.crte.2009.10.003

Lucas A. (2012) Brazil's emerald industry. $G \uplus G$, Vol. 48, No. 1, pp. 73-77, http://dx.doi.org/10.5741/GEMS.48.1.73

Lydekker R.L. (1883) The geology of the Kashmir and Chamba territories, and the British district of Khagan. Memoirs of the Geological Survey of India, Vol. 22, 344 pp.

Martins S. (2018) Brazilian emeralds. Second World Emerald Symposium, October 12-14, Bogotá.

Meng F., Shmelev V.R., Kulikova K.V., Ren Y. (2018) A red corundumbearing vein in the Rai-Iz ultramafic rocks, Polar Urals, Russia: The product of fluid activity in a subduction zone. Lithos, Vol. 320321, pp. 302-314, http://dx.doi.org/10.1016/j.lithos.2018.09.025

Mercier A., Debat P., Saul J.M. (1999) Exotic origin of the ruby deposits of the Mangari area in SE Kenya. Ore Geology Reviews, Vol. 14, No. 2, pp. 83-104, http://dx.doi.org/10.1016/S0169$1368(99) 00002-5$

Nicollet C. (1986) Saphirine et staurotide riche en magnésium et chrome dans les amphibolites et anorthosites à corindon du Vohibory Sud, Madagascar. Bulletin de Minéralogie, Vol. 109, No. 5, pp. 599-612, http://dx.doi.org/10.3406/bulmi.1986.7961

Ottaway T.L., Wicks F.J., Bryndzia L.T., Kyser T.K., Spooner E.T.C. (1994) Formation of the Muzo hydrothermal emerald deposit in Colombia. Nature, Vol. 369, No. 6481, pp. 552-554, http://dx.doi.org/10.1038/369552a0

Ozerov K. (1945) Form of corundum crystals as dependent upon chemical composition of medium. Doklady Akademii Nauk SSSR, Vol. 47, pp. 49-52.

Palke A.C., Renfro N.D., Berg R.B. (2016) Origin of sapphires from a lamprophyre dike at Yogo Gulch, Montana, USA: Clues from their melt inclusions. Lithos, Vol. 260, pp. 339-344, http://dx.doi.org/10.1016/j.lithos.2016.06.004

Palke A.C., Renfro N.D., Berg R.B. (2017) Melt inclusions in alluvial sapphires from Montana, USA: Formation of sapphires as restitic component of lower crustal melting? Lithos, Vol. 278281, pp. 43-53, http://dx.doi.org/10.1016/j.lithos.2017.01.026

Palke A.C., Wong J., Verdel C., Avila J.N. (2018) A common origin for Thai/Cambodian rubies and blue and violet sapphires from Yogo Gulch, Montana, USA? American Mineralogist, Vol. 103, No. 3, pp. 469-479, http://dx.doi.org/10.2138/am-2018-6164

Paquette J.L., Nédelec A., Moine B., Rakotondrazafy A.F.M. (1994) $\mathrm{U}-\mathrm{Pb}$, single zircon $\mathrm{Pb}$-evaporation and $\mathrm{Sm}-\mathrm{Nd}$ isotopic study of a granulite domain in SE Madagascar. Journal of Geology, Vol. 102, No. 5, pp. 523-538, http://dx.doi.org/10.1086/629696

Pardieu V. (2018) Gemfields' November 2017 ruby auction yields record results. InColor, No. 37, pp. 62-63.

Pardieu V., Chauviré B. (2013) Les rubis du Mozambique. Le Règne Minéral, Cahier No. 2, pp. 101-108.

Pardieu V., Rakotosaona N. (2012) Ruby and sapphire rush near
Didy, Madagascar (April-June 2012). GIA Research News, https://www.gia.edu/doc/Ruby-and-Sapphire-Rush-Near-DidyMadagascar.pdf

Pardieu V., Jacquat S., Bryl L.P., Senoble J.B. (2009) Rubies from northern Mozambique. InColor, No. 12, pp. 32-36.

Peretti A., Hahn L. (2013) Record-breaking discovery of ruby and sapphire at the Didy mine in Madagascar: Investigating the source. InColor, No. 21, pp. 22-35.

Peretti A., Mullis J., Kündig R. (1990) Die Kaschmir-Saphire und ihr geologisches erinnerungsvermögen. Neue Zürcher Zeitung, Vol. 187, pp. 58-59.

Peretti A., Peretti F., Kanpraphai A., Bieri W.P., Hametner K., Günther D. (2008) Winza rubies identified. Contributions to Gemology, Vol. 7, pp.1-97.

Peucat J.J., Ruffault P., Fritsch E., Bouhnik-Le Coz M., Simonet C., Lasnier B. (2007) Ga/Mg ratios as a new geochemical tool to differentiate magmatic from metamorphic blue sapphires. Lithos, Vol. 98 , No. 1-4, pp. 261-274, http://dx.doi.org/10.1016/j.lithos.2007.05.001

Rakotondrazafy A.F.M., Moine B., Cuney, M. (1996) Mode of formation of hibonite $\left(\mathrm{CaAl}_{12} \mathrm{O}_{19}\right)$ within the U-Th skarns from the granulites of S-E Madagascar. Contributions to Mineralogy and Petrology, Vol. 123, pp. 190-201, http://dx.doi.org/ $10.1007 / \mathrm{s} 004100050150$

Rakotondrazafy A.F.M., Giuliani G., Ohnenstetter D., Fallick A.E., Andriamamonjy A., Rakotosamizanany S., Ralantoarison T., Razanatseheno M., Offant Y., Garnier V., Maluski H., Dunaigre C., Schwarz D., Mercier A., Ratrimo V., Ralison B. (2008) Gem corundum deposits of Madagascar: A review. Ore Geology Reviews, Vol. 34, No. 1-2, pp. 134-154, http://dx.doi.org/10.1016/i.oregeorev.2007.05.001

Rakotosamizanany S., Giuliani G., Ohnenstetter D., Rakotondrazafy A.F.M., Fallick A.E., Paquette J.-L., Tiepolo M. (2014) Chemical and oxygen isotopic compositions, age and origin of gem corundums in Madagascar alkali basalts. Journal of African Earth Sciences, Vol. 94, pp. 156-170, http://dx.doi.org/10.1016/j.jafrearsci. 2013.06.003

Ramdhor R., Milisenda C.C. (2004) Neue Vorkommen von saphirseifenlager stätten auf Nosy-Bé, Madagaskar. Zeitschrift der Deutschen Gemmologischen Gesellschaft, Vol. 53, No. 4, pp. $143-158$.

Ratnaraj ruby ring highlight of Christie's Hong Kong Magnificent Jewels sale (2017) InColor, No. 34, pp. 76.

Renfro N.D., Palke A.C., Berg R.B. (2018) Gemological characterization of sapphires from Yogo Gulch, Montana. Ge G, Vol. 54, No. 2, pp. 184-201, http://dx.doi.org/10.5741/GEMS.54.2.184

Rudnick R.L., Gao S. (2003) Composition of the continental crust. In R.L. Rudnick, Ed., The Crust. Treatise on Geochemistry Series, Vol. 3. Elsevier Science, Amsterdam, pp. 1-64.

Sabot B., Cheilletz A., De Donato P., Banks D., Levresse G., Barrès O. (2000) Afghan emeralds face Colombian cousins. Chronique de la Recherche Minière, Vol. 541, pp. 111-114.

Schwarz D. (1998) Aus Basalten, Marmoren und Pegmatiten. Spezielle Ursachen formten in der Erdkruste edle Rubine und Saphire. In C. Weise, Ed., Rubin, Saphir, Korund: schön, hart, selten, kostbar. extraLapis, No. 15, pp. 5-9.

Schwarz D., Giuliani G. (2002) South America: Brazil. extraLapis English, No. 2, 46-51.

Schwarz D., Kanis J., Kinnaird J. (1996) Emerald and green beryl from central Nigeria. Journal of Gemmology, Vol. 25, No. 2, pp. $117-141$

Schwarz D., Kanis J., Schmetzer K. (2000) Sapphires from Antsiranana Province, Northern Madagascar. $G \uplus G$, Vol. 36, No. 3, pp. 216-233, http://dx.doi.org/10.5741/GEMS.36.3.216

Schwarz D., Giuliani G., Grundmann G., Glas M. (2002) The origin of emerald...a controversial topic. extraLapis English, No. 2, 1821.

Schwarz D., Pardieu V., Saul J.M., Schmetzer K., Laurs B.M., Giuliani G., Klemm L., Malsy A.-K., Hauzenberger C., Du Toit G., Fallick A.E., Ohnenstetter D. (2008) Ruby and sapphires from Winza, central Tanzania. Gや G, Vol. 44, No. 4, pp. 322-347, 
http://dx.doi.org/10.5741/GEMS.44.4.322

Seifert A.V., Hyršl J. (1999) Sapphire and garnet from Kalalani, Tanga Province, Tanzania. GせG, Vol. 35, No. 2, pp. 108-120, http://dx.doi.org/10.5741/GEMS.35.2.108

Seifert A.V., Žáček V., Vrána S., Pecina V., Zachariáš J., Zwaan J.C. (2004) Emerald Mineralization in the Kafubu area, Zambia. Bulletin of Geosciences, Vol. 79, No. 1, pp. 1-40.

Silva K.K.M.W., Siriwardena, C.H.E.R (1988) Geology and the origin of the corundum-bearing skarn at Bakamuna, Sri Lanka. Mineralium Deposita, Vol. 23, No. 3, pp. 186-190, http://dx.doi.org/10.1007/BF00204299

Simonet C. (2000) Géologie des gisements de saphir et de rubis. L'exemple de la John Saul ruby mine, Mangare, Kenya. Ph.D. thesis, Université de Nantes, $349 \mathrm{pp}$

Simonet C. (2018) The Montepuez ruby deposits, what's next? InColor, No. 37, pp. 32-40.

Simonet C., Paquette J.L., Pin C., Lasnier B., Fritsch E. (2004) The Dusi (Garba Tula) sapphire deposit, Central Kenya-a unique Pan-African corundum-bearing monzonite. Journal of African Earth Sciences, Vol. 38, No. 4, pp. 401-410, http://dx.doi.org/ 10.1016/j.jafrearsci.2004.02.002

Simonet C., Fritsch E., Lasnier B. (2008) A classification of gem corundum deposits aimed towards gem exploration. Ore Geology Reviews, Vol. 34, No. 1-2, pp. 127-133, http://dx.doi.org/ 10.1016/i.oregeorev.2007.09.002

Solesbury F. (1967) Gem corundum pegmatites in NE Tanganyika. Economic Geology, Vol. 62, No. 7, pp. 983-991, http://dx.doi.org/10.2113/gsecongeo.62.7.983

Sorokina E.S., Rösel D., Häger T., Mertz-Kraus R., Saul J.M. (2017a) LA-ICP-MS U-Pb dating of rutile inclusions within corundum (ruby and sapphire): New constraints on the formation of corundum deposits along the Mozambique belt. Mineralium Deposita, Vol. 52, No. 5, pp. 641-649, http://dx.doi.org/10.1007/ s00126-017-0732-x

Sorokina E.S., Karampelas S., Nishanbaev T.P., Nikandrov S.N., Semiannikov B.S. (2017b) Sapphire megacrysts in syenite pegmatites from the Ilmen Mountains, South Urals, Russia: New mineralogical data. Canadian Mineralogist, Vol. 55, No. 5, pp. 823-843, http://dx.doi.org/10.3749/canmin.1700016

SRK Consulting (UK) Limited (2015) A Competent Persons Report on the Montepuez Ruby Project, Mozambique. July 2015, 195 pp.

Sutherland F.L., Abduriyim A. (2009) Geographic typing of gem corundum: A test case from Australia. Journal of Gemmology, Vol. 31, No. 5-8, pp. 203-210.

Sutherland F.L., Schwarz D. (2001) Origin of gem corundums from basaltic fields. Australian Gemmologist, Vol. 21, No. 1, pp. 30-33.

Sutherland F.L., Hoskin P.W.O., Fanning C.M., Coenraads R.R. (1998a) Models of corundum origin from alkali basaltic terrains: A reappraisal. Contributions to Mineralogy and Petrology, Vol. 133, No. 4, pp. 356-372, http://dx.doi.org/10.1007/s004100050458

Sutherland F.L., Schwarz D., Jobbins E.A., Coenraads R.R., Webb G.B. (1998b) Distinctive gem corundum suites from discrete basalt fields: A comparative study of Barrington, Australia, and West Pailin, Cambodia, gemfields. Journal of Gemmology, Vol. 26, No. 2, pp. 65-85.

Sutherland F.L., Zaw K., Meffre S., Giuliani G., Fallick A.E., Graham I.T., Webb G.B. (2009) Gem-corundum megacrysts from east Australian basalt fields: Trace elements, oxygen isotopes and origins. Australian Journal of Earth Sciences, Vol. 56, No. 7, pp. 1003-1022, http://dx.doi.org/10.1080/08120090903112109

Tenthorey E.A., Ryan J.G., Snow E.A. (1996) Petrogenesis of sapphirine-bearing metatroctolites from the Buck Creek ultramafic body, southern Appalachians. Journal of Metamorphic Geology, Vol. 14, No. 2, pp. 103-114, http://dx.doi.org/10.1046/j.15251314.1996.05793.x

Themelis T. (1992) The Heat Treatment of Ruby and Sapphire. Gemlab Inc., Bangkok, 256 pp.

Uher P., Giuliani G., Szakall S., Fallick A.E., Strunga V., Vaculovic D., Ozdin D., Greganova M. (2012) Sapphires related to alkali basalts from the Cerová Highlands, Western Carpathians (southern Slovakia): Composition and origin. Geologica Carpathica, Vol. 63, No. 1, pp. 71-82, http://dx.doi.org/10.2478/v10096-0120005-7

Vapnik Y., Moroz I. (2000) Fluid inclusions in emerald from the Jos Complex (central Nigeria). Schweizerische Mineralogische und Petrographische Mitteilungen, Vol. 80, No. 2, pp. 117-129.

Vapnik Y., Moroz I. (2001) Fluid inclusions in Panjshir emerald (Afghanistan). Proceedings of the XVI European Current Research on Fluid Inclusions (ECROFI), pp. 451-454.

Vapnik Y., Sabot B., Moroz I. (2005) Fluid inclusions in Ianapera emerald, Southern Madagascar. International Geology Review, Vol. 47, No. 6, pp. 647-662, http://dx.doi.org/10.2747/0020 6814.47.6.647

Vapnik Y., Moroz I., Eliezri I. (2006) Formation of emeralds at pegmatite-ultramafic contacts based on fluid inclusions in Kianjavato emerald, Mananjary deposits, Madagascar. Mineralogical Magazine, Vol. 70, No. 2, pp. 141-158, http://dx.doi.org/ $10.1180 / 0026461067020320$

Vertriest W., Girma D., Wongrawang P., Atikarnsakul U., Schumacher K. (2019) Land of origins: A gemological expedition to Ethiopia. GÆ G, Vol. 55, No. 1, pp. 72-88, http://dx.doi.org/ 10.5741/GEMS.55.1.72

Walton L.A. (2004) Exploration criteria for coloured gemstone deposits in the Yukon. Yukon Geological Survey, Open File 2004$10,184 \mathrm{pp}$.

Weil E. (2017) The curse of the Bahia emerald, a giant green rock that ruins lives. Wired, March 2, www.wired.com/2017/03/cursebahia-emerald-giant-green-rock-wreaks-havoc-ruins-lives/

Wise M.A., Anderson A.J. (2006) The emerald- and spodumenebearing quartz veins of the Rist emerald mine, Hiddenite, North Carolina. Canadian Mineralogist, Vol. 44, No. 6, pp. 1529-1541, http://dx.doi.org/10.2113/gscanmin.44.6.1529

Yager T.R., Menzie W.D., Olson D.W. (2008) Weight of production of emeralds, rubies, sapphires, and tanzanite from 1995 through 2005. U.S. Geological Survey Open-File Report 2008-1013, 9 pp., https://pubs.usgs.gov/of/2008/1013/ofr2008-1013.pdf

Yui T.-F., Zaw K., Limkatrun P. (2003) Oxygen isotope composition of the Denchai sapphire, Thailand: A clue to its enigmatic origin. Lithos, Vol. 67, No. 1-2, pp. 153-161, http://dx.doi.org/ 10.1016/S0024-4937/02/00268-2

Zachariáš J., Žáček V., Pudilová M., Machovič V. (2005) Fluid inclusions and stable isotope study of quartz-tourmaline veins associated with beryl and emerald mineralization, Kafubu area Zambia. Chemical Geology, Vol. 223, No. 1-3, pp. 136-152, http://dx.doi.org/10.1016/j.chemgeo.2004.12.023

Zachovay M. (2002) What is the price of an emerald? extraLapis English, No. 2, pp. 93-96.

Zwaan J.C. (2006) Gemmology, geology and origin of the Sandawana emerald deposits, Zimbabwe. Scripta Geologica, Vol 131, pp. 1-211.

Zwaan J.C., Seifert A.V., Vrána S., Laurs B.M., Anckar B., Simmons W.B., Falster A.U., Lustenhouwer W.J., Muhlmeister S., Koivula J.I., Garcia-Guillerminet H. (2005) Emeralds from the Kafubu area, Zambia. $G \uplus G$, Vol. 41, No. 2, pp. 116-148, http://dx.doi.org/10.5741/GEMS.41.2.116 